\title{
Natural enemies associated with some economic pests in Egyptian agro-ecosystems
}

\author{
M. M. El-Husseini ${ }^{1}$, A. H. El-Heneidy ${ }^{2^{*}}$ and K. T. Awadallah ${ }^{1}$
}

\begin{abstract}
No doubt, there are changes in insect pest problems facing the farmers in the newly reclaimed land as well as in the old valley in Egypt due to different reasons, e.g., pesticide misuse and pest resistance, secondary pest outbreaks, absence or inefficient presence of natural enemies, and climate changes. Since the 1990s, the Ministry of Agriculture and Land Reclamation emphasizes to spread the philosophy of integrated pest management (IPM) among the farmers to utilize all suitable means, techniques, and approaches for maintaining pest population levels below those causing economic losses. Among these means is understanding the role of natural enemies in the agro-ecosystem to preserve and encourage their presence and enhance their role in suppressing pest populations as a main factor among the IPM strategies. Thus, it is of essential need to know more about the existing natural enemies associated with the key pests of the economic crops representing different agro-ecosystems in Egypt to develop a successful utilization of biological control agents within the frame of such IPM programs. Thus, it was found necessary to update their recent status as natural resources in various agro-ecosystems. These data are considered a review article eagerly needed for strategies of IPM of serious insect and mite pests in Egypt. The role of the biological control agents, mainly parasitoids and predators in different economic crops, is highlighted.
\end{abstract}

\section{Background}

The intensification of land reclamation for agriculture in Egypt in the last four decades is continuing to meet the needs of the growing human population in the country. Such agricultural development requires contribution of all related agricultural sciences, especially those of plant protection. No doubt, there are changes in insect pest problems facing the farmers in the newly reclaimed land as well as in the old valley due to different reasons, e.g., pesticide misuse and pest resistance, secondary pest outbreaks, climate changes, and absence or inefficient presence of natural enemies. Since the 1990s, the Ministry of Agriculture and Land Reclamation emphasizes the philosophy of integrated pest management (IPM) among the farmers to utilize the suitable means, techniques, and approaches for maintaining pest population levels below economic losses. Among these means is understanding the role of natural enemies in the agro-ecosystem to preserve and encourage their presence and enhance their role in suppressing pest populations as a cornerstone within the IPM strategies. Thus, it is of essential need to know more about the existing natural enemies associated with the key pests attacking economic crops representing different agro-ecosystems in Egypt to develop a successful utilization of biological control agents within the frame of IPM programs.

The various biocontrol agents recorded in the unpublished list titled "List of natural enemies of various insect pests recorded in Egypt" by Tawfik and Awadallah (1992) and the survey followed by Tawfik (2002) are mentioned here apart from their actual validity and efficiency against their prey/host species in the environment. El-Husseini (2015) shed light on the most important effective native and introduced parasitoid and predatory species of main economic insect pests in Egypt. Thus, it was found necessary to update their more recent status as natural resources in various agro-ecosystems.

The presented data could be considered a review article eagerly needed for integrated control of serious insect and mite pests in Egypt.

\footnotetext{
* Correspondence: aelheneidy@gmail.com

${ }^{2}$ Biological Control Department, Agricultural Research Center, Giza, Egypt Full list of author information is available at the end of the article
} 


\section{Investigated agro-ecosystems \\ Field crops \\ Cotton fields}

The cotton leafworm, Spodoptera littoralis (Boisd.) (Noctuidae), and the bollworms, especially the pink bollworm, Pectinophora gossypiella Saund. (Gelechiidae), and the spiny bollworm, Earias insulana Boisd. (Noctuidae), may be, fairly, considered the most injurious pests in cotton fields in Egypt (Hafez et al. 1969).

From extensive samples of all immature forms of the cotton leaf worm collected by Hafez et al. (1976) from cotton fields in all Egyptian Governorates, the main parasitoid species secured were the braconid parasitoids, Chelonus inanitus (L.), Apanteles ruficrus (Haliday), and Microplitis rufiventris Kok.; the ichneumonid Zele chlorophthalma (Nees); and the tachinids Exorista larvarum (L.) and Strobliomyia aegyptia Vill., emerged from the host larvae and pupae. No parasitoids emerged from the host eggs. Trichogramma evanescens West. and T. minutum Riley were reported earlier by Kamal (1951) as parasitoids of $S$. littoralis eggs on cotton. As an evaluation, it seems that, nowadays, the parasitoid complex of $S$. littoralis does not play an efficient role in controlling the population of this pest in Egypt, as it was used in the earlier years. Before the excessive use of pesticides, parasitoids used to cause as high as $75 \%$ mortality among the collected leaf worm populations of the winter brood and approximately $32 \%$ during the summer months (Kamal 1951). The deterioration of parasitism rate is, most probably, attributed to the widespread use of chemical pesticides, particularly in cotton fields, which receive about $70 \%$ of the total amount of pesticide applications, used for pest control in all cultivated crops combined (El-Heneidy et al. 2015). The most important feature in the pattern of parasitism upon the larvae of $S$. littoralis is represented by the change of the leading species from the two tachinnids E. larvarum and $S$. aegyptia in the past to the abovementioned braconid parasitoids (Hassanein et al. 1985). Recently, the high host fraction of parasitism is caused by $M$. rufiventris (25-82\%), followed by C. inanitus (32-53\%), and the lowest by the ichneumonid $Z$. chlorophthalma which is found in extremely low densities.

The bollworms $P$. gossypiella and E. insulana are the most injurious pests in cotton; the former is distributed all over the country, while the latter is more common in Upper Egypt. As for P. gossypiella, the hymenopterous parasitoids Exeristes roborator Fabr. (Ichneumonidae), Chelonus sulcatus Nees, Bracon brevicornis Wesm., and Apanteles platyedrae Wlk. (Braconidae) and the pyemotid mite Pyemotes herfsi Oud. were reported also, by Hafez et al. (1969). E. roborator is distributed in both Lower and Middle Egypt, as there is no evidence of its occurrence south in the Governorates of Upper Egypt. It has 6-15 generations/year, in comparison to about 6 generations of the pink bollworm. The fourth generation of $P$. gossypiella which dominates almost all the month of September is highly parasitized, while its sixth generation, which appears in November, extends for about 4 months during which the majority of larvae enters into diapause from October to just before the host breaks its resting period in April/May. Thus, the newly emerged parasitoid females deposit their eggs on the diapausing bollworm larvae within dry bolls where the parasitoid progeny develops during spring on these larvae. The rate of parasitism by E. roborator on $P$. gossypiella was relatively low (9.7\% at the maximum), and its active period on this host during cotton season in the field was relatively short (1-2 months/year). It attacks only the full-grown larvae in dry bolls; its direct effect on the host is rather restricted, and its role is to affect the population of the host of the subsequent season but not to prevent the direct injury which occurs in the green bolls. Other parasitoids, i.e., C. sulcatus, A. platyedrae, and $B$. brevicornis, have the same role, but they are less abundant. The first parasitoid, C. sulcatus, is found all over Egypt, increases in September, just after harvesting cotton, and its activity continues during October and early November. The second one, A. platyedrae, is more distributed in Upper Egypt than in Lower Egypt. The parasitic mite, $P$. herfsi, distributes in all cotton-growing Governorates where it attacks resting larvae of the pink bollworm in dry bolls or within infested seeds by the end of the season. It plays an important role in reducing populations of this pest; $84 \%$ parasitism was reported for this active biocontrol agent (Farrag 1976). Metwally and Shenouda (1976) stated that no more than $6 \%$ of the active larvae of $P$. gossypiella, found on cotton squares, flowers, and bolls, died, mostly by factors other than the parasitoids and predators. About $96 \%$ of the diapausing larvae were killed, during the resting period by the aforementioned parasitoids. These agents, as shown above, play their role at the end of the season and thus do not prevent the direct injury that occurs in the green bolls during the season. For this reason, efforts have been directed towards introducing egg or egg-larval parasitoids capable to do the job or towards augmentation of endemic egg-larval parasitoids, as C. sulcata.

No accurate information is published, hitherto, concerning the role played by the indigenous natural enemies against the spiny bollworm, E. insulana. A survey was conducted by Eid (1992) to shed light on this aspect and showed that this pest is not suffering from the endemic parasitoids, which are of very rare occurrence and represented, mostly, by the egg parasitoid $T$. evanescens West. and an unidentified egg-larval parasitoid belonging to the genus Chelonus, which reproduce parthenogenetically. The American cotton bollworm, Helicoverpa armigera Hübner (Noctuidae), is accidentally distributed 
as it is under effective control by several parasitic species, i.e., the braconids A. ruficrus, B. brevicornis, and M. rufiventris; the ichneumonids Barylypa humeralis Brann., B. rufa Holargon, and Campoplex xanthostoma Grav.; an encyrtid polyembryonic parasitoid Copidosoma sp.; and the tachinids $E$. larvarum and $S$. aegyptia (Final report of the Egyptian project on natural enemies of H. armigera in Egypt).

Through an American-Egyptian collaboration project titled "Cotton IPM with emphasis on biological control of bollworms" carried out between 1991 and 1994 directed by El-Heneidy, the role of some exotic parasitoid species, the egg parasitoid Trichogrammatoidea bactrae (N.) and the two larval parasitoids Goniozus legneri Gordh and G. pakmanus (G. Gordh \& Ellington), in controlling the pink bollworm was evaluated. Mass rearing and releases of these parasitoids took place in two Governorates (Kafr El-Sheikh and Sharkia). Through an Egyptian Histological arthritis severity in recipientproject entitled "Evaluation of exotic parasitoids against the pink bollworm (PBW) P. gossypiella in cotton," carried out between 1997 and 2000, percentage of infestation with PBW on cotton plants declined by 36 and 55\% (El-Heneidy and Abdel-Hafez 2001). The first two parasitoids have been well established and became already available in the Egyptian agro-ecosystems. Some researchers have made significant contributions to the aspect of biological control of cotton bollworms by parasitoids: Abd El-Hafez et al. (2002), Mesbah et al. (2003), El-Heneidy et al. (2004), and Hend et al. (2016), as already several mass-rearing units, governmental and private, for Trichogramma spp. have been established and distributed in most of the cotton regions in the country, as well as El-Husseini et al. (2008a), who successfully applied T. evanescens for controlling pink and spiny bollworms in fields of organic cotton production in Egypt.

A suggestion was reported by El-Husseini et al. (2000) to leave stripes of clover (15-20 m wide) for seed production between cotton fields each 50 or $100 \mathrm{~m}$. These stripes served in attracting large populations of different beneficial insects mostly Orius spp., especially during clover flowering period, and became the source from which they moved by clover dryness to the adjacent cotton fields (mid-May/June) on each side performing a successful suppression of all cotton pests during this period.

Agrotis ipsilon Rott. (Lepidoptera: Agrotidae) is the most abundant species of cutworm seedlings in Egypt, and it is relatively considered one of the most injurious pests of cotton seedlings. A survey carried out by El-Heneidy and Hassanein (1987) showed two endoparasitoids, Apanteles ruficrus $\mathrm{Hal}$. and Meteorus rubens Nees, found attacking larvae of this pest. However, percentages of parasitism were not high, reaching a maximum of (27.7\%), and M. rubens appeared more active than $A$. ruficrus.
The cotton whitefly, Bemisia tabaci (Genn.), has recently developed to a rather serious pest on several crops including cotton because of the expansion in application of organic pesticides, especially pyrethroids, presumably leading to change in the natural balance between pests and their natural enemies. A survey carried out in cotton fields during 1983-1984 exhibited three parasitoid species attacking $B$. tabaci, Prospaltella lutae Masi, Eretmocerus mundus Mercet, and Encarsia artenopae Masi. E. mundus appeared very active, playing a main regulating factor of population of this pest in cotton fields (Hafez et al. 1978-1979), where (46\%) parasitism was recorded in Lower Egypt and (59-71\%) in Upper Egypt. A high rate of parasitism (98\%) was also reported for this parasitoid against the pest on Lantana camara Linnaeus, which was unexposed to pesticide treatment. In 1984/1985, the average rate of parasitism decreased to $7.9-33.8 \%$ on larvae and $44.2-60.6 \%$ on pupae of $B$. tabaci because of the intensive use of pesticides in cotton fields.

The cotton aphid, Aphis gossypii Glover, became more abundant with recent intensive applications of insecticides. The parasitoid species found associated with this pest in cotton fields are still unstudied, most probably due to their uncommon existence. Two species, one belonging to the genus Aphelinus and the other to Aphidius, were reported (Abul-Nasr and El-Nahal 1963).

Many predatory species exist in cotton fields where they play an important role against most of the pests attacking this crop (El-Heneidy et al. 1996, 1997). This group of predators consists of the dermapteran, Labidura riparia Pallas; the hemipterans, Onocephalus pilicornis H.S. (Reduviidae), Orius albidipennis Reut., and $O$. laevigatus Fieb. (Anthocoridae); and the neuropterans, Chrysoperla carnea (Steph), (Chrysopidae) and Helicomiitus festivus Ramb. (Ascalapidae); the coleopterans, Calosoma chlorostictcum De Geer (Carabidae), Chilomenes vicina Muls, Coccinella undecimpunctata L., C. septempunctata L., Scynmus interruptus Goeze and Scymnus syriacus Mars. (Coccinellidae), and Paederus alfierii Kock. (Staphylinidae); the dipterans, Phenobremia aphidivora Rubs (Cecidomyiidae), Paragus aegyptius Macq., and Sphaerophoria flavicauda Zett. (Syrphidae); and lastly, the phytoseiid mite Amblyseius gossipi El-Badry. Among these agents, the most common are $L$. riparia against larvae and pupae of lepidopterous pests; the anthocorids against egg masses of S. littoralis; the chrysopids against aphids, whitefly, and mites; and Am. gossipi against eggs and larvae of the whitefly. Based on $28 \mathrm{~S}$ rDNA, Gamila et al. (2016), molecularly, identified five coccinellid species from field crops at Giza region, i.e., Coccinella undecimpunctata, C. septempunctata, Cydonia vicina isis, C. vicina nilotica, and Hippodamia variegata. 
Since the 1990s, the applied IPM program in cotton fields depends mainly on avoiding pesticide use against the early- and middle-season cotton pests (the sucking insects and $S$. littoralis) to conserve and enhance the role of parasitoids and predators that migrate from the clover fields to the cotton fields (by May and June). Use of pesticides is only recommended in case of exceeding the economic threshold of the infestation rate with bollworms $(3-5 \%)$.

\section{Corn fields}

The most detailed work on the insect fauna of corn fields was that carried out in Giza by Tawfik et al. (1974). Their studies showed that corn fields are inhabited by representatives of 66 families from 14 orders. About 40 of these species have been recorded as corn feeders. Among them, the three corn borers Sesamia cretica Led., Chilo agamemnon Bles, and Ostrinia nubilalis (Hb.) and the aphid species Macrosiphum (=Sitobion) avenae F., Rhopalosiphum padi L., and $R$. maidis Fitch. are considered the major pests of corn plants in Egypt. Sometimes, and in some areas, the cotton leafworm S. littoralis, the greasy cutworm A. ipsilon, and the mole cricket Gryllotalpa gryllotalpa L. could be destructive to these plants. However, the pest status in corn fields is associated with the existence of 42 beneficial species which play efficiently, as biological control agents, against these pests. Aphids are controlled by several predaceous species, such as the nymphs and adults of the anthocorids Orius albidipennis Fieb. and $O$. laevigatus Fieb. (the former is more common than the latter); adults of the staphylinid Paederus alfierii Kock.; larvae and adults of the coccinellids Cydonia (=Chilomenes) vicina var. isis Cr. and var. nilotica Muls, Coccinella undecimpunctata L., Scymnus interruptus, and S. syriacus; larvae of the syrphids Syrphus corollae Fabre, Sphaerophoria flavicauda Zett, and Paragus aegyptium Macq.; and larvae of the octhiphilid Leucopis puncticornus aphidivora Rond. Aphids, on corn, are parasitized by the braconid species Aphidius sonchi Marsh and Praon flavinoda $\mathrm{Hal}$.

In Egypt, the three corn borers represent the most serious pest species of corn plants that cause high damages. Egg masses and newly hatched larvae of the aforementioned corn borers, and other lepidopterous pests, are subject to attacks by the anthocorids, the coccinellids, and the rove beetles mentioned above. However, coccinellids prefer aphids than lepidopterous pests, while syrphids are more restricted to aphids and are less frequently distributed. An anthocorid, namely, Blastostethus piceus pallescens Poppius, an accidentally introduced species, is commonly found attacking the larvae of Pyroderces simplex Wlsm. on the ears. Tawfik and El-Sherif (1969) found that larvae of $P$. simplex feed during the early stages on young leaves, silk, and pollen grains of maize but old larvae bore into the kernels inducing serious damage to the ears. A braconid wasp belongs to the genus Psychotria was found frequently parasitizing these larvae. This parasitoid plays together with the aforementioned anthocorid predators an important role in controlling the population of this pest.

A group of parasitoids consists of Platytelenomus hylas Nixon, Conomorium eremita Foerster, and T. evanescens present in the fauna of corn plants; the first is specific egg parasitoid on $S$. cretica, the second parasitizes pupae of the same pest, and the third is well known as egg parasitoid of most lepidopterous pests but prefers eggs of C. agamemnon and O. nubilalis more than S. cretica. Economic importance of the egg parasitoid P. hylas on the eggs of S. cretica was assessed in Egypt, by Hafez et al. (1979) during the period 1968-1971. It was found that in most cases, almost all natural mortality of the borer eggs was caused through parasitism by $P$. hylas. Rate of parasitism starts very low at the beginning of the season, during April and May, and reaches a peak of accumulated parasitism late in the season during September and October when the parasitoid starts to hibernate within the host eggs. During the 4 years of work, the highest rates of parasitism ranged between 92 and 95\% in autumn. At certain localities, these rates reached 100\% during August-October. El-Heneidy and Hassanein (1992) recorded the gregarious braconid parasitoid, Meteorus rubens Nees, for the first time in Egypt, on larvae of $S$. cretica in maize fields at Giza Governorate.

Mass production and release of $T$. evanescens induced efficient control of C. agamemnon in corn, rice, and sugarcane fields and is one of the successfully achieved programs for using biological control agents in Egypt (El-Heneidy et al. 1991).

Faunal work in corn fields at Mansoura Governorate, carried out by Ragab (1988), showed most of the beneficial species mentioned above, in addition to the dermapteran, Diaperasticus erythrocephalus (Olivier) (Forficulidae), as first recorded species predaceous upon aphids, egg masses, and young larvae of corn borers. This forficulid was studied by Tawfik et al. (1995), and their observations revealed its predaceous and phytophagous feeding habits. On the other hand, Lutfallah and Kares (1988-89) reported the braconid Bracon brevicornis (Wesm.) as a larval parasitoid of $O$. nubilalis and $C$. agamemnon, in addition to most of the predators mentioned above. $B$. brevicornis was also recorded, as an efficient parasitoid, on the hibernated larvae of corn borers in dry corn stalks during winter (Abd El-Gawad 2000).

A survey on the soil inhabiting predaceous arthropods of Sesamia pupae in sorghum fields, carried out by Temerak (1978-1979), included many predators, i.e., Labidura riparia Pallas and Labia minor L. (Dermaptera; Labiduridae), and the coleopterans, Agrypnus notodonta 
Latr. and Drasterius binaculatus Ros(Elateridae); Paederus alfierii, Philonthus misor Rossi, Ph. turbidus Er., and Scopaeus debilis Koch (Staphylinidae); and Gonocephalus sp. and Opatrum punculatus Braull (Tenebrionidae), and the true spiders Lycosa ferox Lucas., L. urbana apo, Paradosa ventrix Lucas (Lycosidae), and Paradosa sp. (Areneidae). Corn plants are good shelters for many harmful and beneficial insects, during adverse environmental conditions. Small aggregations of $C$. undecimpunctata adults were observed by Tawfik et al. (1974) during May hidden at the bases of leaves when climatic conditions were unsuitable for aphids' existence.

In the applied IPM program in maize fields, the present recommendation of the Ministry of Agriculture refers to delaying the sowing date to be between mid-May to mid-June, to avoid the high infestation by the first generation (exit from the hibernation) of S. cretica to the corn plants. This undoubtedly can help the natural enemies' conservation in this agro-ecosystem.

\section{Cereal fields}

Cereal plants (wheat and barley) are attacked by few numbers of pests; the most injurious are aphids. El-Heneidy and Attia (1988-1989) reported five aphid species: Schizaphis graminum (Rond), Sitobion avenae F., Rhopalosiphum maidis F., R. padi (L.), and Diuraphis noxia Mord. as main pests of wheat plants in Beni Suef and Fayoum Governorates. High rates of infestation occur during March. Two hymenopterous species, Diaeretiella rapae M. and Aphidius spp. (Fam. Braconidae), were found parasitizing these aphid species. Percentages of parasitism reported were low, ranging between 6 and 9\%. The authors reported that the aphidophagous predators, C. undecimpunctata, Scymnus spp., Ch. carnea, $P$. alfierii, and true spiders, increased gradually towards the end of the season and peaked during April. Dominant occurrence of C. undecimpunctata was quite clear during the season. In Giza and Kafr El-Sheikh, Ibrahim and Amal (1991a) recorded the primary parasitoids, Aphidius matricariae Hal., A. uzbekistanicus Luz., and Praon gallicum Hal., associated with Sitobion avenae F.; A. matricariae was the most dominant one. These parasitoids were subjected to be attacked by four secondary parasitoids namely, Alloxysta sp., Phaenoglypha sp. (Cynipidae), Asaphas sp., and Pachyneuron sp. (Pteromalidae). Ibrahim (1990) previously reported these primary and secondary parasitoids for the aphid S. graminum in wheat. Five syrphid species were secured, i.e., Metasyrphus (=Syrphus) corollae Fabr., Lasiophthious (=Scaeva) albomaculata Macq., Sphaerophoria flavicauda Zett., Xanthogramma aegyptium Weid., and Paragus aegyptius Macq. This group proved as the first dominant aphidophagous predators. There were the coccinellids, C. undecimpunctata and Chilomenes vicina var. isis and var. nilotica; the first species was the highest in abundance, and the chrysopid, C. carnea, occupied the lowest status among all the collected predators (Ibrahim and Amal 1991b). El-Heneidy et al. (2001b) published an extensive survey of the primary and secondary parasitoid species on key wheat aphid species in most of the wheat cultivations in Egypt (12 Governorates), which covers most of those reported by other authors including the Aphidiidae $A$. matricariae Haliday, A. colemani Viereck, and D. rapae. Mc'Intosh, Paron necans Mackauer, Ephedrus persicae Haliday, and Trioxys sp.; the Aphilinidae Aphelinus albipodus Hayat \& Fatima and the secondary parasitoids; the cynipid Alloxysta (Chalcidididae); the pteromalids (Asaphes and Pachyneuron); and the encyrtids Aphidencyrtus sp., Megaspilidae, and Dendrocerus (=Lygocerus) sp. They found that the aphidiids and the aphelinids were represented by 96.3 and 3.2\%, respectively. The genus Aphidius (A. matricariae and A. colemani) predominated slightly over the other genera of Aphidiidae (35.5\%), followed by Diaeretiella (34.4\%). D. rapae was followed by P. necans (25.6\%). The cynipids were the most dominant secondary parasitoid species (78.1\%), followed by the chalcids (9.7\%). Obtained data showed that the total percentage of hyperparasitism all over the country (12 Governorates) reached 21.2\%. Native Aphelinus sp. which emerged from cereal aphid species, collected from Egyptian wheat fields, was identified as Aphelinus albipodus Hayat and Fatima (Adly 2008).

On barley, Ibrahim (1990) recorded four aphid species, i.e., S. graminum, $R$. maidis, $R$. padi, and $S$. avenae, parasitized by the three hymenopterans, A. matricariae, $P$. gallicum, and A. uzbekistanicus. These primary parasitoids were found playing an important role against the aforementioned aphids, especially by the end of March, when $A$. matricariae was the most efficient species (60-64\% parasitism), while the least efficacy was reported for P. gallicum (27-25\%). However, the primary parasitoids were attacked by the four secondary ones previously mentioned in the case of wheat fields, added to them a fifth one namely Dendrocereus sp. (Megaspilidae). Alloxysta sp. was the most predominant hyperparasitoid as in wheat fields. Same occurrence of the abovementioned predators on wheat was reported for barley.

A comprehensive work was given by El-Heneidy and Adly (2012) as a review article concerning aphid parasitoid species infesting cereal crops and their weeds in Egypt. They indicated their seasonal abundance as well as their economic thresholds and efficiency of insecticides against their natural enemies and recorded the primary and secondary parasitoids and predators which were recognized in Egypt.

Recently, Neveen et al. (2017) reported 11 aphidiine parasitoid species, belonging to six genera (Aphidius Nees, Binodoxys Mackauer, Diaeretiella Starý, Ephedrus 
Haliday, Lysiphlebus Foerster, and Praon Haliday) from three aphid species [Rhopalosiphum maidis (Fitch), Rhopalosiphum padi (L.), and Sitobium avenae (F.)], feeding on four cereal plants (Avena sativa L., Hordeum vulgare L., Triticum aestivum L., and Zea mays L.) in Egypt. They provided a key, indicating the tritrophic (parasitoid-aphid-plant) associations of the recorded aphidiines and their distribution in the target area. Among the emerged parasitoids, Aphidius ervi Haliday was a new record for the fauna of Egypt. Aphidius transcaspicus Telenga and Binodoxys angelicae (Haliday) were reported for the first time to be associated with aphids infesting cereals in Egypt.

\section{Rice fields}

In Egypt, rice is subjected to infestation by several species of pests among which the most common are the blood worm Chironomus sp., maggots of the tabanid Atylotus agrestis (Wied.), and the rice stem borer Chilo agamemnon Bles. By several practices towards the first pest, it became possible to get very satisfactory cultural control results. A. agrestis could be found in enormous numbers in the field, particularly when livestock manure is used for fertilization. Level of infestation becomes lower in early-planted fields and in less susceptible varieties to infestation. No biological control agents are reported, hitherto, for both pests. The rice stem borer $C$. agamemnon is considered the most destructive to rice plants. Estimated losses in rice yield in Egypt due to this pest range between 3 and 7\%. These losses differ considerably according to variety, date of sowing, locality, and rate of nitrogen fertilization (Sherif et al. 2005).

There are many natural enemies, which play an important role against rice pests, especially $C$. agamemnon (Tantawy; personal communication). There are two species of true spiders; one belongs to the genus Lycosa (Fam. Lycosidae) and the other is Areneus inustus (Fam. Araneidae), both predating on moths of the rice stem borer, the cotton leaf worm, and the rice butterfly. Some predaceous insects are also found in the rice fields feeding vigorously on eggs and young larvae of these insects. Among these predators are Reduvius pallipes (Reduviidae), the staphylinid Paederus alfierii Koch., and some anthocorids. It appears, also, that the egg parasitoid $T$. evanescens West. plays a promising role against the stem borer, especially late in the season (time of the fourth generation of this pest). Consequently, a natural range of parasitism (95.5-96.2\%) was recorded (Sherif et al. 2005). Accordingly, it was recommended, in the first symposium of the Egyptian Society of Biological Control of Pests (ESBCP) that was held in Cairo in February 1992, not to undertake any insecticidal application in rice fields, except when degree of infestation with the rice stem borer exceeds the economic threshold $<$ ) $7 \%$ (. In the frame of the
IPM program in rice fields, utilization of $T$. evanescens through inundative releases has been highly recommended in case of high infestation with the pest.

\section{Sugarcane fields}

A survey of the insect fauna of sugarcane fields in Upper Egypt referred to 13 insect genera as sugarcane feeders (Ezzat and Atries 1967). These are Aiolopsis and Locusta (Acrididae), Labia (Dermaptera), Phyllodromia (Blattidae), Geotomus (Cydnidae), Empoasca and Exitianus (Jassidae), Tropidocephala (Delphacidae), Chilo (Grambidae), Pelopidus (Hesperiidae), Leucania (Noctuidae), Dorylus (Formicidae), and Pentondon (Scaraebidae). The authors mentioned that although the apparent serious damage to sugarcane in Egypt is mainly due to the lepidopterous sugarcane and corn borer Chilo agamemnon Bles., all other pests in the aforementioned genera had different degrees of importance. However, the fauna included a considerable number of useful insects providing the bright aspect of the picture. The most reliable species in this beneficial group are concentrated in the orders Hemiptera, Neuroptera, Diptera, Hymenoptera, and Coleoptera. From Hemiptera, the anthocorid Orius sp.? niger is known as predator on insect eggs, mites, small insects, and aphids. Two reduviids, Oncocephalus notatus Klug and Pirates sterpitans rufipennis Lucas, were also reported as bloodsuckers of other insects. In Neuroptera, Chrysopa vulgaris (=Chrysoperla carnea) Steph. and Cueta variegata Klug were recorded. The former species is also known as predaceous on the sugarcane mealybug, Saccharicoccus sacchari Ckll., and other pests. Among Diptera, two syrphids were recorded, Syritta spinigera Loew and Syrphus corollae F., which are known to be predaceous upon aphids and nymphs of other homopterous insects. Also, the sarcophagid Sarcophaga rapax Walk. was recorded; it plays a role in controlling the sugarcane moth borer, Diatraea saccharalis Fabricius. Among the Hymenoptera, members of family Ichneumonidae include Diplazon laetorius Fabr. and Barylypa humeralis Branus (L.P.); the first is known as a parasitoid of syrphids and the second of Lepidoptera. A single parasitic species was reported for either Encyrtidae or Trichogrmmatidae, i.e., Homalitylioidae and $T$. evanescens, respectively. Since the 1980s, great efforts have been carried out by the Ministry of Agriculture to utilize this parasitoid T. evanescens against $C$. agamemnon in sugarcane fields by mass rearing and inundative releases of the parasitoid through 14 mass-rearing units, covering all the sugarcane areas $(300,000$ feddans $=120,000$ ha) (El-Samea and Saadia 2002). Through the implementation of this program, the infestation with $C$. agamemnon in sugarcane fields was reduced successfully from 17 to $>3 \%$ in almost all the sugarcane fields. In the above authors' list, other hymenopterous species of known beneficial role are present, i.e., Myzine arabica Guer. (Scoliidae) that 
works as ectoparasitoid on larvae of Scarabidae; Chrysis sp. (Chrysididae) parasitizes certain caterpillars; Eumenes maxillosa F. (Eumenidae), Ammophila tyedi Guill., Liris praetermissa Rich, Phillanthus triangulum abdelkader Luc., and Sceliphron sprifex L. (Sphecidae) feeders on collected young lepidopterous larvae; and Paracyphononyx ruficrus Klug and Pompilus sp. (Pompilidae) known as predators of spiders. Among the Coleoptera, the coccinelids Chilomenes vicina Muls, C. undecimpunctata, and Scymnus syriacus (Goeze) are well known as predators in sugarcane fields in different parts of the world. The authors mentioned that the first coccinellid attacks different young insects; the second mainly attacks the mealybugs $S$. sacchari and Symicoccus bonsis, while the third feeds on coleopterous pests. The two staphylinids, Paederus alfierii Koch and Philonthus longicornis, were also reported; the first is a well-known predator of insect eggs and young larvae or nymphs or insect pest, and the latter most probably feeds on insect stages inhabiting the soil, e.g., pupae of Chilo. Five carabids, Calosoma levantinus leavistriatus Schatz., Broscus punctatus Dej., Calosoma rugosum chlorostictum Klug., Microlestes sp., and Tachys lucasi Duv., were included in the list. Their activity is restricted in feeding on various stages of insects inhabiting soil.

From the aforementioned data, it becomes obvious that the insect fauna in sugarcane fields in Upper Egypt includes numerous insect groups, few of which are causing some damage and the rest of other groups forming a complex of species of possible benefit. No pesticide treatments are carried out in sugarcane fields, and thus, some kind of conservation of biocontrol agents is taking place. However, the most destructive species in these fields consist mainly of the borer C. agamemnon and partially the mealy-bug $S$. sacchari. The former pest is now controlled by inundative releases of the egg parasitoid, T. evanescens, and the populations of the latter pest are associated with a newly recorded predator, Diaperasticus erythrocephalus (Olivier) (Dermeptera; Forficulidae), found by Ragab (1988) in Lower Egypt (Dakahlia Governorate). El-Serwy (2002) stated that the red-striped soft scale, Pulvinaria tenuivalvata (Newstead) (Hemiptera: Coccidae), on sugarcane is parasitized by Coccophagus semicircularis (Foerster) (Aphelinidae); Metaphycus flavus (Howard), Microterys sp., and Microterys nietenri (Motschulsky); Diversinervus elegans Silvestri (Encyrtidae); and Pachyneuron muscarum (Linnaeus) (Pteromalidae). The highest rate of parasitism upon females of this pest at El-Aiat (Giza Governorate) reached 90, 77.3, and $75 \%$ in late October, mid-November, and early January. The corresponding rates at Atfieh at the same Governorate were 56, 60.7 , and $58.3 \%$ and attained the highest rate of $78 \%$ by late January. On nymphs, the rates were 40.6, 98.7, and $100 \%$ by late November, December, and January, respectively, and attained the highest rate of $78 \%$ by late January.
On the other hand, seven predators, Scymnus glivifrons Muls. and Stethorus punctillum Wiese (Coccinellidae), Phaleria sp. (Tenebrionidae), Ch. carnea. (Chrysopidae), Orius laevigatus (Fiebe) (Anthocoridae), Anatrachyntis rileyi (Walsingham) (Cosomopterigidae), and an unidentified ceccidomyiid, were found associated with this pest at the same location. Also, four predaceous mites, Amblyseius swirski Athias-Henroit and Typhlodromus pelargonicus (Phytoseiidae), Agistemus exsertus Gonzalez (Stigmaeidae), and Anystus sp. (Anystidae), were recorded (Karam and Sanaa 1992).

\section{Clover fields}

Egyptian clover, Trifolium alexandrinum L., is the principal forage crop in Egypt, and thus, no chemical control applications against pests take place on it. In a survey of insect fauna of this crop carried out by Tawfik et al. (1976b) at Giza, 35 species of parasitoids and predators were recorded. These agents are undoubtedly protected. The predators are as follows: Orius spp. (Anthocoridae); Deraecoris punctulaus (Miridae); Geocoris megacephalus (Lygaeidae); Ch. carnea (Chrysopidae); Bembidion sp. (Carabidae), Paederus alfierii Koch., Platystethus degener, Carpelimus sp., and Tachyperu sp. (Staphylinidae); Coccinella undecimpunctata L., C. septempunctata L., Cydonia vicina var. nilotica, and Scymnus interruptus (Coccinellidae); Anoplius infuscatus Goeze (Pompilidae); Vespa orientalis, Polistes gallica (Vespidae), and Platypalpus (Empidae); and Syrphus corollae Fabr., Sphaerophoria flavicauda Zett., Xanthogramma aegyptium Wied., and Paragus aegyptius Macq. (Syrphidae). The commonly occurring predators are C.carnea, P. alfierii, C. undecimpunctata, and S. corollae, while the occasionally occurring ones are Orius spp., S. interruptus, S. flavicauda, Xanthgramma aegyptium, Paragas aegyptius, and Platypalpus sp.

Parasitoid species found in clover fields, at Giza, were the ichneumonids Diplazon sp., Grelis sp., Casinaria sp., Mythobia (Angitia) sp., Barylypa rufa, and Bathyplectes curculionis Thoms.; the braconids M. rufiventris, Apanteles sp., Opius sp., and Zele chlorophthalma Nees; the pteromalids Habrocytus sequester Walk. and Pteromalus puparum L.; and the tachinid E. larvarum. The most known species are $B$. rufa, the larval pupal parasitoid of S. littoralis; B. curculionis, the larval parasitoid of Hypera brunneipennis Boh.; M. rufiventris, E. larvarum and $Z$. chlorophthalma; the larval parasitoids of S. littoralis; and Pteromalus puparum L., the pupal parasitoid of Pieris rapae. The role played by other parasitoids is still unknown. Kolaib et al. (1980) recorded the parasitoids $M$. rufiventris, Z. chlorophthalma, and Zele sp. near Zele nigricrnis, C. inanitus, Barlypa spp., and S. aegyptia and two unidentified tachinids on the cotton leafworm in clover fields at Alexandria. Boraei (1993) gave the first 
record of Microctonus sp. on the Egyptian alfalfa weevil (Hypera brunneipennis Boh.) in Egypt. Higher levels of parasitism were observed when larvae were dissected during the years of 1992 and 1993 showing 20 and 44\% parasitism, respectively, with an overall mean of $40 \%$. According to the above information, it seems that clover fields are very good habitats for numerous biological control agents that distribute safely in these fields far from any chemical control application. Strip harvesting of clover in these fields, undoubtedly, conserves and encourages propagation and the role played by these agents in various agro-ecosystems (El-Husseini et al. 2000).

\section{Horticultural crops Vegetable crops}

From the extensive samples collected from vegetable crop fields in Upper and Lower Egypt by Hassanein et al. (1985), 12 species of well-known lepidopterous pests and their parasitoids were recorded. On tomato, S. littoralis, Phthorimaea operculella, H. armigera, and Autographa sp. were the main insect pests. On the first pest, the parasitoid species $M$. rufiventris and S. aegyptia were recorded. Bracon instabilis Marshal (L.P.) and Apanteles litae operculellae Nixon were secured from $P$. operculella, while the parasitoids E. larvarum and Apanteles sp. were found associated with $H$. armigera. On potato, $P$. operculella was the most destructive pest, where the three parasitoids Apanteles litae var. operculellae Nixon, Bracon instabilis Marshal, and Diadegma mollipum Hlmgrn were found parasitizing the pest. Cabbage was severely attacked by S. littoralis, S. exiga, Autographa spp. Pieris rapae, Helulla undalis Fabr., and Plutella xylostella Linnacus. On this crop, S. littoralis was found attacked by five parasitic species: $M$. rufiventris, Ch. inanitus, Z. chlorophthalma, S. aegyptia, and Meteorus gyrator Thunberd. P. puparum and Brachymeria femorata Panz. were encountered on $P$. rapae. Apanteles ruficrus Hal. and Apanteles sp. were found parasitic on Autographa sp., while $M$. rufiventris emerged from $S$. exigua only in Upper Egypt. The authors for P. xylostella reported no parasitic species, but Abbas and Hassanein (1989) found it attacked by the ichneumonid Hyposoter ebeninus Grav. Samples collected by Hassanein et al. (1985) from eggplant fields showed also a high infestation with $P$. operculella and low infestation with $A$. ipsilon, Euzophora osseatella Tr., and $H$. armigera. No D. molliplum nor $B$. instabilis were recorded on $P$. operculella, while A. ruficrus was sometimes found parasitizing A. ipsilon. Jew's mallow was found attacked by S. littoralis, S. exigua, $H$. armigera, and A. ipsilon. M. rufiventris, Z. chlorophthalma, M. gyrator, and S. aegyptia parasitized the first pest. Beans were infested by $S$. littoralis, $S$. exigua, Autographa sp., and Cosmolyce baeticus L. Mainly, M. rufiventris and partly $S$. aegyptia were the common parasitoids of $S$. littoralis on the two mentioned crops. A. ruficrus was reported for C. baeticus, and $M$. rufiventris was less frequent on S. exigua. No parasitoids attacked Autographa spp. on mallow and beans. Cowpea plants suffered from infestations by $S$. littoralis, S. exigua, and A. ipsilon that were parasitized by $M$. rufiventris, S. aegyptia, and $M$. gyrator. M. gyrator parasitized only S. littoralis. Okra was severely attacked by S. littoralis, E. insulana, and Autographa spp. where no parasitoids were secured from the two latter pests, while few parasitoid individuals ( $M$. rufiventris, $M$. gyrator, Z. chlorophthalma, and S. egyptia) were recorded on S. littoralis. Eid (1992) reported that E. insulana on okra plants was very poorly parasitized by unidentified egg-larval parasitoid belonging to the genus Chelonus. Hassanein et al. (1985) found four lepidopterous pests infesting Egyptian Mallow, i.e., S. littoralis, Autographa sp., H. armigera, and Vanessa cardui. No parasitoids emerged from the last two pests, while $S$. aegyptia was secured from S. littoralis, and Apanteles sp. from Autographa sp. S. littoralis on artichoke was seen parasitized by the tachinid S. aegyptia, and Autographa sp. on cauliflower by the baraconid A. ruficrus. El-Husseini et al. (2006a) studied the parasitoid Trissulcus basalis Wollaston, as an important egg parasitoid on eggs of the green stinkbug Nezara viridual (L.) in okra fields in El Beheira Governorate, where its parasitism rate reached 90-100\%. In a newly reclaimed Egyptian land, Meabed et al. (2011) applied successful releases of T. evanescsens in potato fields to suppress the infestation by the potato tuber moth, $P$. operculella. On the basis of the aforementioned observations, it appeared that among the 12 lepidopterous pests attacking vegetable crops, the most destructive ones were $S$. littoralis and $P$. operculella. On the other hand, the most common parasitoid was $M$. rufiventris, followed descendingly by $S$. aegyptia, M. gyrator, B. instabilis, and lastly Z. chlorophthalma.

Ibrahim and Fayad (1983) surveyed the aphids attacking vegetable crops and their associated parasitoid species. They reported an unidentified species from the family Braconidae as a parasitoid of Aphis craccivora Koch and Acyrothosiphon pesui on French beans and the aphidiid Diaeretiella rapae Mc'Intosh parasitizing Brevicoryne brassicae L. on cabbage, cauliflower, turnip, and radish. Kolaib (1991) reported the rate of parasitism caused by the latter parasitoid on the cabbage aphid, as well as the rate of hyperparasitism on D. rapae in Menofia Governorate. The former rate reached a mean of $96.4 \%$ during December, referring to the high efficacy of the primary parasitoid $D$. rapae. Rate of hyperparasitism peaked on January (91\%) through the secondary parasitoids, Pachyneuron aphidis Bouche and Alloxysta sp. Hassanein et al. (1993) found the braconid Opius nitidulator (Nees) parasitizing the full grown larvae of Pegomia 
mixta Villenouva, the important dipteran pest of sugar beet in Egypt.

El-Agamy et al. (1994) found two trichogrammatid parasitoid species attacking eggs of the lepidopterous pests infesting Monothochaeta nigra Blood and Krugger and the gregarious larval parasitoid Tetrastichus sp. (Hymenoptera: Eulophidae). Percentage of parasitism reported for the first parasitoid ranged between 10.1 and $15.5 \%$, while that of the second one was 3.7 and $5.3 \%$. Leaf-mining insects and their parasitoids need thorough investigations. There are plenty of species which are not recorded yet. However, Metwally (1991) recorded four parasitoids on Liriomyza trifolii attacking cowpea. Those were Halticoptera circulus Walker, Anagyrus sp., Chrysonotomyi sp., and Hemiptarsenas zilahisbessi. The highest rate of parasitism (33.9\%) occurred in mid-October.

Recently, Askar and El Husseini (2016) recorded the ichneumonid Sinophorus xanthostomus (Gravenhorst) parasitizing Artogia (Pieris) rapae L. in cabbage fields at El Beheira Governorate. They also recorded the eulophid parasitoid Tetrastichus galactopus (Ratzeburg) as a hyperparasitoid on S. xanthostomus in P. rapae. Furthermore, Askar and El Husseini (2016) studied the dispersal of $P$. puparum and T. evanescens parasitizing $A$. rapae at El Beheira Governorate.

The whitefly Bemisia tabaci Genn. may be fairly considered one of the major insect pests on a wide range of vegetable crops, especially Cucurbitaceae, Solanaceae, and Crucifereae, since this pest is a vector of serious virus diseases. It appears that biological control with its known natural enemies does not represent, solely, a sufficient control measure (Hafez et al. 1978-1979).

In 2009, the South American tomato leaf miner Tuta absoluta (Meyrick) (Lepidoptera: Gelechiidae) was detected as an invasive neotropical pest in Egypt. It is one of the most destructive insect pests of tomato that threats yield production. Preliminary survey of its indigenous parasitoid species in Egypt revealed the records of Trichogramma spp. on eggs and the larval parasitoids Necremnus artynes (Walker) on L2 and L3 and Bracon (=Habrobracon) nigricans on mature larvae in both open fields and greenhouses during spring and summer tomato plantations (Zappala et al. 2013).

\section{Fruit crops}

Orchard plant pests Natural enemies associated with orchard plant pests are numerous and mostly efficient, but they did not receive considerable investigations compared with those reported on pests of the field crops. Orchards represent more stable agro-ecosystems, and thus, efforts directed towards biological control of their pests would be a more successful control measure. The present status of natural enemies in these agro-ecosystems that referred recently is restricted to pests infesting the most economic fruit crops.

Citrus orchards Citrus represents one of the most important fruit crops in Egypt, as well as it is one of the best competitors in the world. That is why great care is paid nowadays to citrus orchards from the standpoint of horticultural procedures and pest control. Citrus plants are infested with different pests of which scale insects, e.g., the California red scale, Aonidiella aurantii Mask., and the purple scale, Lepidosaphes beckii (Newm.), are now the most destructive. In the past, the black scale Chrysomphalus ficus Ashmed was the most common pest species on citrus, but now, it is under the control of many biocontrol agents, especially the encyrtid endoparasitoid Habrolepis pascuorum Mercet. which is widely spread all the months of the year. Tawfik et al. (1970) recorded this parasitoid among other parasitoids of the same pests, i.e., Aphytis chrysomphali Mercet (Aphelinidae) and Aphychus flavus Howard (Encyrtidae). The role of the former species had drastically declined, possibly due to competition and replacement by $H$. pascuorum. The latter parasitoid was reported earlier as parasitic on Coccus hesperidum Linneaus, Eriococcus orgenseni, Pulvinaria iceryi, and Saissetia oleae Bern and later was observed by Tawfik et al. (1970) through very small numbers restricted to only few and localized samples collected from citrus. It was stated by Abul-Nasr and El-Nahal (1963) that the citrus mealybug Planococcus citri Risso is kept under control by the two encyrtid parasitoids, Anagyrus pseudococci Gir. and Leptomastidea sp. In a more recent investigation, Morsi (1999) stated that C. ficus Ashm. is attacked in Beni-Suef Governorate by the parasitoids Aphytis citrinus Comp., A. chrysomphalli, A. lingnanensis, Encarsia sp., Marrietta exitiosa Comp. (Aphelinidae), and H. pascuorum (Encyrtidae). On the other hand, Hekal and Sakr (2001) reported the aphelinid parasitoid, Aphytis holoxanthus Debach, as a new record attacking the same scale insect. They added that this parasitoid was accidentally entered from Israel to Egypt during the beginning of the 1980s, causing the gradual scarcity of $C$. ficus and the entire displacement of $A$. chrysomphali. In a survey of the natural enemies of scale insects on citrus, Mahmoud (1981) studied their status in association with the most common scales, $A$. aurantii Mask. and L. beckii. For the former pest, an Aphytis sp. was reported as the most important ectoparasitoid on adult females. The increase in its population density during winter resulted in an obvious decrease in that of its pest. Another primary endoparasitoid, Habrolepis aspidisti Compere, was also recorded, being more abundant during summer than in winter. A hyperparasitoid, Aspidiophagus sp. was found attacking the 
aforementioned primary parasitoids but was not of a common occurrence.

On sour orange, Morsi (1999) recorded the parasitoids Aphytis melinus Debach and Coccophagoids sp. (Aphelinidae) and Habrolepis aspidioti Comp. \& Ann. (Encyrtidae) on the same scale insect at Beni-Suef Governorate. On the other hand, only one species, i.e., Aphytis lepidosaphes (Comper) was found by Mahmoud (1981) parasitic on pre-adult and adult females of $L$. beckii Newn whose population was greatly suppressed due to the active role played by this parasitoid, especially during February and March. In summer, this role was affected badly due to the attacks of a secondary parasitoid, namely Marietta exitosa Compere (Aphelinidae).

El-Husseini et al. (1994) studied the seasonal fluctuations of $A$. lepidosaphes parasitizing $L$. beckii during the two seasons (1985/1987) in citrus plantations which were kept free from any chemical application. The first season was characterized by a relatively higher rate of parasitism (54.4\%) than the second season (23.4\%). The maximum rate of parasitism (46.0\%) took place in May during the second season. Nymphs and females of L. beckii seemed to be more favorable for the parasitoid than males. The average values of annual fluctuations were 1.404 and 2.768 for the first and second seasons, respectively.

An outbreak of the citrus leaf miner Phylocnistis citrella Stainton was recorded in the 1994 season in almost all citrus orchards all over Egypt. It was a minor pest infesting citrus trees since the 1980s. A survey of the parasitoid species of $P$. citrella was carried out by Tawfik et al. (1996), which resulted in seven hymenopterous species. Identified parasitoids showed four eulophid species, Cirrospillus pictus (Nees), Ratzoburgiola incompleta Boucck., and Sympiesis sp. The other two species were Prigalio sp. and Baryscapus sp. Lamia; Abo Abdalla (2015) recorded four hymenopterous parasitoid species: Cirrospilus sp., Zagrammosoma sp., Pnigalio sp., and Baryscapus sp. (family Eulophidae) parasitizing Cirrospillus pictus in Alexandria, Egypt. The species Cirrospilus sp. was the dominant one through the 2 years of study (2012 and 2013).

A group of predators was found associated with the scale insects on citrus. Among the predaceous insects, the two coccinellids, Chilochorus bipustulatus L. and Scymnus syriacus March, were reported by Tawfik et al. (1970) (for C. ficus) and Mahmoud (1981) for A. aurantii and $L$. beckii. The former predator was considered by both authors as the most efficient. Metwally et al. (1999) at Kafr El-Sheikh Governorate (northern Egypt) studied seasonal abundance of the coccinellid predator, Clitostethus arcuatus (Rossi). This predator accounted $41.9 \%$ of the total number of predators found associated with the citrus whitefly Dialeurodes citri (Ashm.) on citrus trees, where a mean number of the predator reached 15 individuals/80 double net-strokes, as described.

Hamed and Saad (1989) observed the coccinellid Rodolia cardinalis Mulsant adapting its known feeding habit from Icerya purchasi Mask. to I. aegyptiaca (Douglas) on the same crop as previously mentioned by Tawfik et al. (1970) and Mahmoud (1981). Chrysopa was also recorded as a predator during larval stage on crawlers of these pests. Tawfik et al. (1970) included the two predators Pharoscymnus varis Kirsch (Coccinellidae) and Cybocephalus flavipes Reitt. (Nitidulidae) which were not reported later by Mahmoud (1981) who found the phlaeothripid Haplothrips cahirensis (Tryb) as a predator upon different stages of $L$. beckii and A. aurantii during the period from March to October. The anthocorid Cardiostethus nazarenus Reui. was also reported by Tawfik et al. (1976a) as a predator of $L$. beckii on citrus.

Morsi (1999) surveyed the natural enemies of the scale insects on citrus trees at Beni-Suef Governorate and found the insect predators Scymnus includens Kirsch, S. subasciatus jumperi Mots, S. syriacus Marsuel, Stethorus puncutellum Weise (Coccinellidae), Chrysoperla carnea Steph. (Chrysopidae), and predaceous mites Euseins scutalis Athias-Henriot and Proctolaelaps orientalis Nasr attacking $A$. aurantii on baladi orange and Scymnus syriacus, Chilocorus bipustulatus L., Exochomus nigromaculatus Goeze, Pharoscymnus varius, Rodolia cardinalis Muls, and C. carnea attacking C. ficus on mandarin.

Several predaceous mites exist on citrus trees playing an active role against scale insects. Mahmoud (1981) reported a eupalopsellid mite Eupalopsellus oleratus Gomma. as a predator on eggs and crawlers of $L$. beckii and A. aurantii. Zaher (1986) recorded nine species of mites feeding on scale insects in Egypt. Those were Agistemus exsertus Gonzalez. (Stigmaeidae) on C. ficus and L. bekii, Neophyllobius magniferus Zaher \& Gomaa. (Neophyllobiidae) (on C. ficus), Saniosulus nudus Summers. (Eupalopsellidae) on L. beckii and L. tableyi, Eupalosellus olearius Zaher \& Gomaa. (Eupalopsellidae) on L. ulmi, Cheletogenes ornatus Canestrini \& Fanzago, Hemicheyletia backeri Ehara. (Cheyletidae) on different scale insects, Typhlodromus magniferans Zaher \& El-Brallosy, and Amblyseius gossipi El-Badry. (Phytoseiidae) on C. ficus. The same author found the cunaxid mite, Cunax capreolus, and the phytoseiid mite, Typhlodromus magnifera, feeding on the phytophagous mite, Eutetranychus orientalis, on citrus.

Morsi (1999) recorded Agistemus excertus Gonz., Blattiscus tarsalis Berlese (Ascidae), and Tydeus californicus Banks (Stigmaeiidae) as predaceous mites against $C$. ficus, Euseins cutalis Athias-Henriot, and Proctolaclaps orientalis Nasr on A. aurantii on citrus at Beni-Suef Governorate. Zaher (1986) had observed the phytoseiid mite Amblyseius gossipi attacking whiteflies. Rakha and El-Naggar (1993) studied the relationship between 
predaceous mites and citrus pests in two different localities in Egypt, Qalyobia (Nile Valley) and Beheira (Coastal lands). The phytoseiid mite E. scutalis was the most commonly encountered predator associated with phytophagous mites and whiteflies, while the predatory cheyletid mite Cheletogenes ornatus Canestrini and Fanzogo was the most abundant species associated with scale insects. Recently, El-Husseini et al. (2011) recorded Crosidura sp. (Insectivora: Soricidae) as a key predator suppressing naturally the populations of the scarabaeid hairy rose shafer Tropinota squalida Scop. in the desert agro-ecosystem in deciduous fruit orchards.

Olive orchards Olive is one of the important economical crops in Egypt. Olive trees are attacked by insect pests that affect quality and quantity of the yield. On olive trees, populations of the fruit fly, Bacteracera (Dacus) oleae Gamel are suppressed by the braconid parasitoid, Opius concolor Szepl. (Ajjan 1962), and those of the olive scale insect Parasaissetia oleae by the pteromalid parasitoid Sautellistea cyanea Mols. (Hosny et al. 1966). The two stem borers, Phlocotribus scarabaeides Bern. and Zeuzera pyrina L. are parasitized by two pteromalids, Cheiropochus quadrum and Rhaphitelus maculatus, and two unidentified species belonging to the genera Euplemus and Eurytoma (Ismail et al. 1988). The shot-hole borer Scolytus amaygdali (Coleoptera: Scolytidae) of olive trees is parasitized during its larval stage by seven hymenopterous parasitoids, i.e., Cerocephala cornigera, Cheiropachus quadrum, Rhaphites maculatus (Pteromalidae), Cephalonoma sp. (Bethylidae), Eupelmus sp. (Eupelmidae), Eurytoma sp. (Eurytomidae), and Leptomastix trunctellus (Encyrtidae) (Ismail et al. 1988). In most recent studies, El-Khawas et al. (2000) presented a detail record concerning parasitoids on common olive pests in Egypt, in Alexandria, Fayoum, and North Sinai Governorates. Opius concolor Szeph. (Braconidae), Prigalio agraules Walker (Eulophidae), Eupelmus sp. and Macroneara sp. (Eurytomidae), Eurytoma martelli Masi and Eurytoma sp. (Eurytomidae), and Cryptoprymna latipes Ronaldi (Pteromalidae) were reported on larvae of Bacterocera (Dacus) oleae, and Prays oleae Bern that feed on leaves, flower buds, and fruits was subject to attack by Apanteles sp. and Bracon sp. (Braconidae), while the Jasmine moth, Palipta unionalis Hb., that feeds on buds was parasitized by Apanteles syleptae F. (Braconidae) and Brachymeria aegyptiaca Masi (Chalcididae). The armored scale insect Leucaspis riccae Targ was attacked by Aphytis sp., while the California red scale $A$. aurantii by Marietta sp. (Aphelinidae) and Habrolepis sp. (Encyrtidae). A recent survey on parasitoids of $B$. oleae carried out by El-Heneidy et al. (2001b) in Alexandria and El-Fayoum Governorates included eight hymenopterous parasitoids namely Cyroptyx latipes R.,
Cyroptyx sp., Eupelmus sp., Eurytoma sp., Eurytoma martelli, Macroneura sp., Prigalio agraules W., and Opius concolor S. The first seven species were recorded for the first time in Egypt. The eighth parasitoid species was recorded in the fresh fruits, while only six were recorded from the fallen fruits. All species were recorded during the period from July to November. Mean percentages of parasitism reached 38.9 and $10.8 \%$ by the two species; $O$. concolor and $P$. agraules, respectively.

Auphyllura phillyreae (Homoptera: Psyllidae) destroys the flower buds through feeding and secreting wax materials on them. In Egypt, this pest was parasitized by the two primary parasitoids Catolaccus crassiceps (Pteromalidae) and Psyllophaga sp. (Encyrtidae) and the secondary ones Pachyneuron sp., P. muscarum, and P. formusum (Braconidae) (Nada 1994).

The most recent studies concerning survey of important pests attacking olive trees and their associated natural enemies were carried out by El-Basha (2002) in Ismailia Governorate. In this survey, many hymenopterous parasitoids were reported for six olive pests, i.e., Psyttalia (Opius) concolor Szepl (Braconidae) on Bactrocera oleae (Diptera: Tephritidae), Psyllaephagus euphyllura (Encyrtidae), Marietta picta Andre (Aphelinidae) and Pachyneuron muscarum (L) (Pteromalidae) on Euphyllura straminea (Homoptera: Aphalaridae), Aphytis sp. (Aphelinidae), Habrolepis sp. (Encyrtidae) and Marietta picta (Andre) (Aphelinidae) on Aspidiotus hedera (Homoptera: Diaspididae), Aphytis sp. (Aphelinidae) on Parlatoria oleae (Homoptera: Diaspididae), Apanteles sp. (Braconidae), Bracon sp. (Braconidae) and Trichogramma sp. (Trichogrammitidae) on Prays oleae (Lepidoptera: Hyponomeutidae), and Apanteles sylepta F. (Braconidae) and B. aegyptiaca (Chalcididae) on $P$. unionalis (Lepidoptera: Pyralidae). These pests were found also associated with the three predators Chrysoperla carnea, Syrphus corollae, and Scymnus sp.

Nasr et al. (2002) recorded Apanteles xanthostigmus Hal. and A. sylepta F., (Braconidae), Xanthopimpla punctata Fr. (Ichneumonidae), and Brachymeria spp. (Chalcididae) on the olive leafmoth $P$. unionalis and $A$. xanthostigmus and Opius concolor Szepl. (Braconidae), Tetrastichus amythestinus Ratz. (Eulophidae), and Hockeria bispinosa Walker and Chalcis modesta Masi. (Chalcididae) on the olive moth Prays oleae Bern in olive groves at Giza and Alexandria. Hegazi et al. (2005) recorded three trichogrammatid species, $T$. cacociae, $T$. bourrachae, and T. cardubensis, parasitizing eggs of the olive pests $P$. unionalis and $P$. oleae in olive orchards, located in the western desert in Egypt.

\section{Other orchard crops}

One of the most destructive pests in orchards is the tephritid Mediterranean fruit fly Ceratitis capitata 
(Wied.) that infests many kinds of fruits, e.g., citrus, apricot, peach, guava, mango, and apples. Serious damage is restricted to citrus, apricot, peach, and guava. Sarhan (1981) reported the pupal parasitoids of this pest species, being the chalcid Euchalicidia caryobori Hanna and the pteromalids Pachycrepoides vindemia (Rodani) and Spalangia gemina Boucek. The rate of parasitism reported for these parasitoids seemed to be low as it does not exceed 9\%, and thus, their role in suppressing the populations of the pest is rather limited. On the other hand, its pupae were found attacked in the soil and under the fallen infested fruits by the earwig Labidura riparia and spiders. No parasitoids were recorded on other stages of C. capitata. El-Minshawy et al. (1999) recorded the peach fruit fly Bactrocera zonata (Saunders) as a new exotic pest of several fruits such as mango, guava, peach, apricot, fig, and citrus in Egypt. El-Husseini et al. (2008a) recorded the chalcidid Dirhinus gifardii (Silvestri) parasitizing the pupae of B. zonata under guava trees in El Kanater region.

Ibrahim (1994) reported Ephedrus persicae Forgatt, A. matricariae, D. rapae, and Praon volucre Hal. as efficient parasitoids of the aphids Myzus persicae (Sulz.), Aphis gossypii (Glov.), and Aphis pomi De Geer on apple trees at Giza Governorate. Parasitism rates of 12.5, 24.6, and 28.7\% were reported for the parasitoids mentioned above. Both $E$. persicae and $A$. matricariae were the dominant and highly effective species against the aphids M. persice and A. gossypii. Rates of 35.9 and $34.1 \%$ of the total percentage of parasitism were found. Ibrahim and Amal (1993) reported the aphid Hyalopterus pruni (Geoff) as a dominant pest on peach leaves in Egypt. They found the parasitoids Aphidius colemani Vier and $A$. picipes (Neas) attacking it, representing a maximum percentage of $(64.5 \%)$ parasitism that recorded in May. Efficient parasitoids of pomegranate pests were the two chalcids B. aegyptiaca (Awadallah et al. 1970) and B. brevicornis (Hosny et al. 1966) on pupae of the pomegranate butterfly Deudorix livia Klug. and T. evanescens on eggs of the same pest (Awadallah et al. 1970).

It is noteworthy to mention in this article that the aphelinid Aphelinus mali Hald., which was introduced to Egypt from the UK in 1934 to control the woolly apple aphid Eriosoma lanigera Hausm (Kamal 1951), has been well established and showed very successful results about controlling the pest in many regions in Egypt.

Shoukry et al. (1997) recorded three parasitoid species attacking the honeydew moth Cryptoblabes gnidiella (Mille) that infests mango in Ismailia Governorate. These parasitoids were the egg-larval braconid wasp Phamerotoma ocularis, the ichneumonid wasp Diadegma aegyptiacum on larvae, and the chalcidid wasp $B$. aegyptiaca on pupae. The highest percentages of parasitism reported for these parasitoids were 32.6, 42.2, and
69.2\% in May and August, respectively, in 1993, and 44.2, 51.3, and 55.5\% in May and June, 1994. The same pest is also subjected to the attacks by the predator Blaptostethus piceus Fieber var. pallescens (Hemiptera: Anthocoridae) that plays an important role in suppressing its population in mango orchards. Also, on mango, Morsi (1999) found that the scale insect Aulacaspis tubercularis Newst was attacked by the parasitoids Aphytis sp., Aspidiotiphagus citrinus Craw (Aphelinidae), Encarsia sp., Haprolepis aspidioti, H. obscura Comp. \& Ann., and Metaphycus sp. (flavus Howard) (Encyrtidae) and an unidentified encyrtid sp. and the insect predators Chilocorus bipusculatus L., Exochomus nigromaculatus Coccinillid, S. syriacus, S. puncutellum, and C. carnea, and the predaceous mites Cheletogenus ornatus Can. \& Fan. (Cheyletidae), E. scutalis, Kleemannia pulmosus Oudem. (Amerosidae), and Tydeus californicus Banks (Stigmaeiidae).

Marwa et al. (2012) studied the parasitism on larvae of the date palm fruits Cadra (Ephestia) cautella (Walker) on dried stored fruits by the braconid ectoparasitoid Habrobracon hebetor Say. The estimated parasitism rate on eggs of C. cautella ranged between 9.5 and $46.3 \%$ by the three different Trichogramma spp. (T. bourorachea, T. evanescens, and T. cacoceciae).

Youssif et al. (2014a, b) recorded the two new predatory species Chrysemosa jeanneli (Navas 1914) (Neuroptera: Chrysopidae) and Wesmaelius navas (Andreu, 1911) (Neuroptera: Hemerobiidae) for the first time in Egypt, on apricot and peach trees associated with the aphid Hyalopterus pruni (Geoffroy) at El-Khattara district, Sharkia Governorate, Egypt, in years 2010 and 2011.

\section{Ornamental crops}

Pests of ornamental plants were also investigated from the standpoint of their natural enemies. On buddlia, Aphis verbasci is commonly distributed as a dominant pest throughout the year. Azab et al. (1965) recorded many insect predators feeding actively on $A$. verbasci, being C. undecimpunctata, Leucopis puncticornis, and Phaenobremia aphidivora (=Aphidoletes aphidimyza). In their studies on the insect fauna of the ornamental tree Ficus nitida, Tawfik (1967) and Maha et al. (2013) reported an unidentified hymenopterous parasitoid belonging to the genus Pleurotropis (Eulophidae) for the larvae of thrips, Gynaikothrips ficorum Marchal (Phlaeothripidae). The same authors also stated that this pest was attacked by the two anthocorid bugs Montandoniella moraguesi Put. and Orius albidipennis Reut., the chrysopid Chrysopa vulgaris (=Chrysoperla carnea), the termatophylid bug Termatophylum insigni Reut., and the predaceous mite Adactylidium sp. (Pyemotidae, now Acarophaenacidae). Adactylidium sp. was identified by Zaher and Kandeed (Zaher 1986) as Adactylidium 
gynaikothripsi. El-Husseini et al. (2006b) studied the biology and incidence of eulophid Pediobius thysanopterus Burks parasitizing G. ficorum on F. nitida trees. Aphis nerii infesting the ornamental tree Nerium oleander was found by Ismail and Swailem (1971) as a favorable prey of the predators Ch. carnea, C. undecimpunctata, Scymnus sp., and some syrphids. Rashad (1975) recorded population densities of the mealybug Ferrisia virigata (Cockerell) (Pseudoccidae) and its natural enemies on Acalypha macrophylla in Giza. For this pest, two hymenopterous parasitoids, namely, Leptomastix sp. (Encyrtidae) and Tetrastichus principiae (Eulophidae), and five predaceous spp., Scymnus includens, Cryptolaemus montrouzieri, Chrysoperla carnea, Sympherobius amicus Navas. (Neuroptera), and Hyperaspis vincigurrae Capra (Coccinellidae), were reported. Swailem et al. (1976) recorded the encyrtid parasitoid Habrolepis sp. on Lindigaspis rossi (Diaspididae) that infests F. nitida and Jasminum pubscens. Hegazi and Moursi (1983) recorded the two hymenopterous parasitoids Antisrophoplex conthurnatus (Masi) (Tormydae) and Pronotalia sp. (Eulophidae) on the capsule fly Acanthiophilus helianthi Rossi infesting safflower. Ragab (1991) found the eggs of the green bug Nezara viridula L. parasitized by the scelionid species, Microphanurus basalis, Stromatum flovum Villers (Cerambycidae) is considered an important stem borer on casuarina trees; Khalafallah (1988-89) found it parasitized by Scleroderma ephippium (Saunders) (Hymenoptera: Bethylidae). Most natural enemies attacking pests of other orchard and ornamental plants are still in need of further investigations. Mousa et al. (2001) reported that among the 60 ornamentals and aromatic host plants of the pink hibiscus mealy bug, Maconellicoccus hirsutus (Green), the most injurious mealy bug species occurring in Egypt, sampled from different Egyptian regions in year 2000, 66.3\% were found parasitized. The survey revealed the presence of eight primary and four secondary parasitoid species. The primary parasitoid species were Allotropa sp. near mecrida (Walker) (Platygastridae); Gyranusoidea indica Shafee, Alam and Agarwal; Leptomastidea abnormis (Girault); Leptomastix algirica Trjapitzin, Leptomastix sp.; Anagyrus kamali Moursi; and Anagyrus sp. and Clausenia sp. (all Encyrtidae), while the secondary species were Chartocerus sp. (Signiphoridae), Marietta sp. (Aphelinidae), Pachyneuron sp. (Pteromalidae), and Prochilonerus bolivari Mercet (Encyrtidae). Gonzalez et al. (2003) reported that although the ornamental hibiscus host plants were found abundantly in Egypt, Spain, and Morocco but pink hibiscus mealybug (PHMB) M. hirsutus was found only in Egypt and among its several parasitoids recovered, the platygastrid gregarious parasitoid species Allotropa sp. near mercida (Walker) was by far the most abundant one attacking PHMB in Egypt.
Through the studies of Priesner and Hosny (1940), El-Nahal et al. (1976), Abdel-Fattah et al. (1984), Awadallah et al. (1999), and Abd-Rabou (1998, 1999a, 1999b, 2000, 2001a, 2001b) more than 40 parasitoid species were recorded on the whiteflies, soft and armored scale insects, and mealy bugs on the ornamental plants and some horticulture crops in different Egyptian agro-ecosystems. The most common genera of the recorded parasitoid species were Aphelinus, Aphytis, Encarsia, Eretomocerus, Encyrtus, Coccophagous, Pteroptrix, and Marietta spp.

Naturally occurring entomopathogenic microorganisms in Egyptian ecosystems did not receive any attention from the entomologists until 1954 when Prof. Abul Nasr got interested in controlling the cotton leaf worm S. littoralis by its nuclear polyhydrosis virus. Although a large spectrum of these agents is available, most species are still unknown, and taxonomic and biological knowledge of the studied agents are fragmentary. Most attention that took place early was paid towards the entomopathogenic bacterium Bacillus thuringiensis revealing various varieties or subspecies, e.g., thuringiensis from S. littoralis (Abdellah and Abul Nasr 1970), P. gossypiella (Farrag 1979), and E. insulana (Abul-Nasr et al. 1978-1979). For fungi, Sewify (1997) reported some information concerning occurrence and pathogenicity of certain economic important species, e.g., Beauveria bassiana, Metahrizium anisopliae, Verticillium lecanii, and Entomophthora sp. The susceptibility of different insect pests to these fungi was investigated by the same author, i.e., Bemesia tabaci, Myzus persicae, and Aphis gossypii to V. lecanii; B. tabci, Cassida vittata, Zeuzera pyrina, and Sesamia critica to B. bassiana; and Z. pyrina, Locusta migratoria, C. vittata, S. littoralis, $P$. gossypiella, and E. insulana to M. anisopliae. Nematodes had also received considerable attention from Egyptian specialists, especially towards species infesting economic plants, while entomopathogenic species were less investigated (El-Kifl et al. 1970). Atwa (1999) reported M. anisopliae infecting important insect pests in Egypt, i.e., Z. pyrina, with two strains of Steinernema carpocapsae (EGB2), Steinernema sp. (EGB20), and two Heterorhabdities bacteriophora (EGB13), H. indicus (EBN 16). Those of Pieris brassicae and S. littoralis were Steinernema sp. (EGB20), H. bacteriophora (EGB13), and H. indicus (EBN16).

Since the polyhydrosis virus of the cotton leaf worm was recorded by Abul-Nasr et al. (1978-1979), many investigations were carried out to investigate the importance of these biological control agents in Egyptian agro-ecosystem. Among these investigations was that of Abol-Ela et al. (1988) who shed light on the different strains of this virus in the cotton leaf worm. Khamiss et al. (1999) recorded the Egyptian isolates of S. littoralis 
granulovirus from cotton fields in Egypt. Fèdière et al. (1999), here also, was the first to isolate densovirus and picornavirus from natural field populations of the same pest in Egypt. Actually, the densonucleosis virus was first recorded in Egypt from the cotton leaf worm by Fediere et al. (1995). It was found necessary to have a future publication concerning exclusively all reported entomopathogenic microorganisms infecting insect pests commonly distributed in Egyptian agro-ecosystems.

\section{Conclusions}

The above data represent an overview and documented status of the most common natural enemies of major and economic insect pests in important Egyptian agro-ecosystems. These will undoubtedly help in planning any strategy needed for integrated pest management in the most important economic crops in Egypt.

First, we are looking forward towards a conservation strategy that embraces preservation and maintenance, rational utilization, and enhancement of the natural biological control agents in these agro-ecosystems. Secondly, the survey reported in this review article will shed light on the parasitoid-predator complex of each pest within which special consideration will be given to the most active agents. These agents should be preserved in the environment, during the course of agricultural practices, or utilized if possible in periodic colonization. Thirdly, this may help in the cases which require introductions of exotic natural enemies eagerly needed to control harmful pests with inactive endemic agents.

\section{Acknowledgements}

The authors appreciate the initial and valuable contribution of the late Prof. Dr. Mohamed F. Tawfik, professor and pioneer in the field of biological control of pests in Egypt. His earlier initiation and suggestions did help so much in the progress of this review article.

\section{Availability of data and materials}

All datasets are presented in the main manuscript.

\section{Authors' contributions}

All authors read and approved the final manuscript.

\section{Ethics approval and consent to participate}

Not applicable

\section{Consent for publication}

Not applicable

\section{Competing interests}

The authors declare that they have no competing interests.

\section{Publisher's Note}

Springer Nature remains neutral with regard to jurisdictional claims in published maps and institutional affiliations.

\section{Author details}

${ }^{1}$ Center of Biological Control, Faculty of Agriculture, Cairo University, Giza, Egypt. ${ }^{2}$ Biological Control Department, Agricultural Research Center, Giza, Egypt.
Received: 6 June 2018 Accepted: 13 September 2018

Published online: 01 October 2018

\section{References}

Abbas MST, Hassanein FA (1989) First record of Hyposoter ebeninus Grav. in Egypt parasitizing Pieris rapae L. larvae in cabbage fields. International Conf. Of econ. Entomol, Cairo Egypt, pp 57-63 December 11-14

Abd El-Gawad HA (2000) Studies on entomopathogenic fungi for controlling certain lepidopterous insects on corn. Ph. D. Thesis, Fac. of Agric. Cairo University, Egypt, p 182pp

Abd El-Hafez A, Shalaby FF, El-Khayat EF, El-Sharakawy MAA (2002) Efficiency of last season, releasing of four trichogrammatid species in suppressing infestation with Pectinophora gossypiella (Saund.) in the cotton fields at Sharkia Governorate. 2nd International Conference, Plant Protection Research Institute, Cairo, Egypt, pp 21-24 Dec., 1: 605-610

Abdel-Fattah MI, Hendi A, Kolrab MO, El-Said A (1984) Studies on Prospaltella lutea Masi (Hymenoptera: Aphelinidae), a primary parasite of the cotton whitefly, Bemisia tabaci (Genn.) in Egypt (Hemiptera: Aleyrodidae). Bull Soc Ent Egypte 65:119-129

Abdellah MD, Abul Nasr S (1970) Feeding behavior of the cotton leaf-worm, Spodoptera littoralis (Boisd.) sublethaly infected with Bacillus thuringiemsis Berliner. Bull Soc Ent Egypte Econ Ser 4:161-170

Abd-Rabou S (1998) A revision of the parasitoids of whiteflies from Egypt. Acta Phyto Et Entomol Hungarica 33:193-215

Abd-Rabou S (1999a) Parasitoids attacking the Egyptian species of armored scale insects (Homoptera: Diaspididae). Egypt J Agric Res 77(3):1113-1128

Abd-Rabou S (1999b) Seven species of super family Chalcidoidea (Hymenoptera) first recorded in Egypt. Egypt J Agric Res 77(3):1205-1214

Abd-Rabou S (2000) Newly recorded Aphelinids and Encrytids in Egypt. Egypt J Agric Res 78(5):1915-1923

Abd-Rabou S (2001a) Parasitoids attacking soft scales (Homoptera: Coccoidea: Coccidae) in Egypt. Egypt J Agric Res 79(3):859-880

Abd-Rabou S (2001b) Parasitoids attack meal bugs (Homoptera Coccoidea: Pseudococcidae) in Egypt. Egypt J Agric Res 79(4):1355-1376

Abol-Ela SM, Remiller M, Khamiss OA, Croizier G (1988) Genomic variation among viral strains isolated from larvae of Spodoptera littoralis (Boisd.) from different regions in Egypt. Bull Fac Agri Cairo University 39(2):655-668

Abul-Nasr S, Ammar ED, Merdan Al (1978-1979) Field application of two strains of Bacillus thuringiensis for the control of the cotton bollworms, Pectinophora gossypiella (Saund.) and Earias insulana (Boisd.). Bull. Soc. ent. Egypte. Econ Ser 11:35-39

Abul-Nasr S, El-Nahal AKM (1963) Agricultural pests and their control (in Arabic), p 633

Adly, Dalia A. (2008). Studies on the parasitoid, Aphelinus albipodus Hayat and Fatima (Hymenoptera: Aphelinidae) for biological control of cereal aphids in Egypt. Ph. D. Thesis, Fac. of Agric., Cairo University, Egypt, 156pp

Ajjan, I. (1962). Biology and control of the olive fruit fly Dacus oleae. M. Sc. Thesis Fac. of Agriculture, Cairo University, Egypt, 133pp

Askar SI, El Husseini MM (2016) On the biology of Tetrastichus galactopus (Ratzeburg) (Hymenoptera: Eulophidae), a hyperparasitoid of Sinophorus xanthostomus (Gravenhorst) parasitizing Pieris rapae L., Egypt. J. Biol. Pest Control 26(3):523-526

Atwa A. A. (1999). Interaction of certain insecticides and entomopathogenic nematodes in controlling some insect pests on fruit and vegetable crops. M. Sc. Thesis, Faculty of Agriculture, Ain Shams University, Cairo, Egypt. 161pp

Awadallah AM, Azab AK, El-Nahal AKM (1970) Studies on the pomegranate butterfly, Virachola livia (Lepidoptera, Lycaenidae). Bull Soc Ent Egypte LIV: $545-567$

Awadallah KT, Brahim AMA, Atia AR, Nada SMA (1999) Survey of mealy bug parasitoids and their associated hyperparasitoids on certain ornamental host plants at Giza region. Bull Ent Soc Egypt 77:97-101

Azab, A.K., M.F.S. Tawfik and I.I. Ismail (1965). Seasonal changes in the abundance of certain aphids and their predators in Giza. Bull Soc Ent Egypte 49: 11-24 XLIX

Boraei HA (1993) Parasitism of Microctonus sp. (Hymenoptera: Braconidae) a newly recorded parasitoid on the Egyptian alfalfa weevil in Egypt. J. Biol. Pest Control 3(2):169-176

Eid, F.M.H. (1992). Studies on natural enemies of the spiny bollworm, Earias insulana (Boisd.). M. Sc. Thesis, Fac. Agric., Cairo Univ., 109 pp.

El-Agamy FM, Metwally SMI, El-Sufty R, Yossef A (1994) On role of parasitoids of the sugarbeet beetle, Cassida vittata de Villers in Kafr El-Sheikh governorate, Egypt. Egypt J Biol Pest Control 4(2):33-38 
El-Basha, N.A. (2002). Biological control of some pests infesting olive trees in Egypt. Ph.D. Thesis, Fac. Agric., Suez Canal Univ. 187pp

El-Heneidy, A. H.; Abbas, M.S.; Imbaby, M.M. and Ewase, M.A. (1991). Utilization of Trichogramma evanescens West. to control the lesser sugar-cane borer, Chilo agamemnon Bles. in sugar cane fields in Egypt. 5 - an approach towards large-scale release. Third Inter. Symposium "Trichogramma and other egg parasitoids". San Antonio (TX, USA), Sept. 23-27, 1990. (Ed.) INRA, Paris, 1991 (Les Colloques N 56, p. 187-189)

El-Heneidy, A.H. and Ali Abdel-Hafez (2001). Annual report of the project Evaluation of exotic parasitoids against cotton bollworms in Egypt

El-Heneidy AH, Adly D (2012) Cereal aphids and their biological control agents in Egypt. Review article. Egypt J Biol Pest Cont 22(2):227-244

El-Heneidy AH, Attia AA (1988-1989) Evaluation to the role of parasitoids and predators associated with aphids in Egypt. Bull ent Soc Egypt Econ Ser 17:147-187

El-Heneidy AH, Fayad YH, Gonzalez D, Abdel-Salam NM, Ellington J, Moawad GM (1996) Pest-predator-interactions in untreated cotton fields at three plant growth stages. 1- location impact. Egypt J Biol Pest Cont 6(1):75-81

El-Heneidy AH, Gonzalez D, Stary P, Adly D, El-Khawas MA (2001 b) Survey of primary and secondary parasitoid species of cereal aphids in Egypt. Egypt J Biol Pest Control 11(2):193-194

El-Heneidy AH, Hassanein FA (1987) Survey of the parasitoids of the greasy cutworm Agrotis ipsilon Rott. (Lepidoptera: Noctuidae) in Egypt. Anz Schädlingskunde und Pflanzenschutz 60:155-157

El-Heneidy AH, Hassanein FA (1992) Meteorus gyrator Thunberg and M. rubens Nees. (Hymenoptera: Braconidae), new recorded parasitoids, on certain Lepidopterous pests in Egypt. Egypt J Agric Res 70(3):797-802

El-Heneidy AH, Ibrahin AA, Gonzalez D, Abdel-Salam NM, Ellington J, Moawad GM (1997) Pest-predator -interactions in untreated cotton fields at three plant growth stages. 2- planting date impact. Egypt J Agric Res 75(1):137-155

El-Heneidy AH, Khidr AA, Abdel-Halim A, Eissa MA, Matter AM (2004) Proper timing and number of releases of the egg parasitoid, Trichogramma evanescens West for controlling the cotton bollworms in Egyptian cotton fields Egypt. J Biol Pest Cont 14(1):15-19

El-Heneidy AH, Khidr AA, Taman AA (2015) Side effects of insecticides on nontarget organisms: 1- In Egyptian Cotton Fields. Egypt. J. Biol. Pest Cont. 25 (3), p.685-690. Proceeding of fourth International Conference, ESPCP2015, Cairo Egypt, 19-22 October 2015

El-Husseini, KAA D, El-Aw MAM, Askar SIS (2006b) Some biological and morphological aspects of Trissulcus basalis Wollaston (Hymenoptera: Scelionidae) an egg parasitoid of Nezara viridula (L.) (Heteroptera: Pentatomidae). Egypt J Biol Pest Control 16(1):111-114

El-Husseini, M.M. (2015). The history of biological control in Egypt: past, present and future. 4th International Conference of Bio-friendly Applied Biological Control of Agricultural Pests and Phytopathogens, Cairo-Egypt, 19-22 October, 2015

El-Husseini MM, Abou Bakr HE, Agamy EA (2011) Preliminary study on the importance of biodiversity for suppressing populations of Tropinota squalida Scop. (Coleoptera: Scarabaeidae) in the newly reclaimed agro-ecosystem in Egypt. Egypt J Biol Pest Control 21(1):153-158

El-Husseini MM, Agamy EA, Saafan MH, Walaa MAE (2008a) On the biology of Dirhinus giffardii (Silvestri) (Hymenoptera: Chalcididae) parasitizing pupae of the peach fruit fly, Bactrocera zonata (Saunders) (Diptera: Tephritidae) in Egypt. Egypt J Biol Pest Control 18(2):391-396

El-Husseini MM, Agamy EA, Sayed SMM (2000) Migration of anthcorids from clover to cotton and its importance for stripe technique in traditional and organic cotton production. Egypt J Biol Pest Control 10(2):75-79

El-Husseini MM, Shahira SHM, Ola OE, Mesbah AH (2006a) On the biology and incidence of the parasitoid, Pediobius (Pleurotropis) thysanopterus Burks (Hymenoptera: Eulophidae) parasitizing the Cubian laural thrips, Gynikothrips ficorum (Marshal) (Thysanoptera: Phlaeothripidae) in Egypt. Egypt J Bio Pest Control 16(2):107-110

El-Husseini MM, Swailem SM, Ahmed GSM (1994) Abundance of Aphytis lepidosaphaes (Comper) (Hymenoptera: Aphelinidae) and its host the purple mussel scale, Lepidosaphes beckii (Newman) of citrus. Egypt J Biol Pest Control 4(1):79-88

El-Khawas MA, El-Heneidy AH, Aziza HO, El-Sherif H (2000) A recent record of parasitoids on common olive pests in Egypt. Egypt J Biol Pest Control 10(1):137-138

El-Kifl AH, Abdel Wahab Al, Ali MAMM (1970) Some insects parasitized by nematodes in Egypt. Bull. Soc. ent. Egypte, LIV, pp 87-99

El-Minshawy AM, Al-Eryan MA, Awad Al (1999) Biological and morphological studies on the guava fruit fly Bactrocera zonata (Diptera: Tephritidae) found recently in Egypt. In: , Proceeding of eighth Nat. Conf. of pest and diseases of vegetables and fruits in Ismailia, Egypt, pp 71-81

El-Nahal AKM, Awadallah KT, Shaheen AA (1976) Abundance and natural enemies of Lepidosphes tapleyi Williams on certain ornamental plants in Giza and Zagazig regions. Bull Soc Ent Egypte 60:311-317

El-Samea Abd, Saadia A. (2002). Laboratory studies on parasitoid, Coccophagus scutellaris (Dalman) (Hymenoptera: Aphelinidae) on the soft scale insect: Pulvinaria tenuivalvata (Newstead), a pest of sugar cane in Egypt. Agric. Res. Rev. (In press)

El-Serwy SA (2002) Ecology, biology and natural enemies of the red-striped soft scale, Pulvinaria tenuivalvata (Newstead) (Hemiptera: Coccidae), a pest of sugar cane in Egypt. Bull ent Soc Egypt 79:13-35

Ezzat YM, Atries IE (1967) A survey on the insect fauna of sugar cane fields in U.A. R. Bull Soc. ent. Egypte, LI, pp 433-446

Farrag, A. R. (1979). Studies on integrated control of some cotton insects. "Factors affecting the control of the two major cotton insects" by Bacillus thuringiensis and Dimilin- Ph.D. Thesis, Fac. Agric., University of Alexandria, Egypt, 143pp

Farrag, S.M. (1976). Studies on the natural mortality of Pectinophora gossypiella Saund. with special reference to its bacterial diseases. M.Sc. Thesis, Fac Agric, Cairo University, Egypt, 125pp

Fediere G, El-Sheikh MAK, Abol-Ela S, Salah M, Masri M, Veyrunes JC (1995) Isolation of a new Densonucleosis virus from Mythimna loreyi Dup. (Lep. Noctuidae) in Egypt. Bull Fac Agric Cairo 46(4):693-702

Fèdière G, Kl-Sheikh MAK, Khamiss O, Masri M, Salah M (1999) Isolation of Densovirus and Picornavirus from natural field populations of Spodoptera littoralis (Boisd). (Lep.: Noctuidae) in Egypt. Mansoura University Journal of Agricultural Sciences 24(11):6945-6953

Gamila YA, El-Husseini MM, Al-Shemi HA, Sayeda SA (2016) Molecular identification of five Egyptian ladybird beetles based on 285 rDNA (Coleoptera: Coccinellidae). Egypt J Biol Pest Control 26(1):153-156

Gonzalez D, El-Heneidy AH, Mousa SM, Triapitsyn SV, Adly D, Triapitsyn VA, Meyerdirk D (2003) A survey for Hibiscus mealy bug, Maconellicoccus hirsutus (Green) and their parasitoids in Egypt, Spain and Morocco. J Biol Pest Control 13(1):1-5

Hafez, M.; A. M. Afifi and D.S. Daoud (1969). On the population dynamics of the cotton bollworms in U.A.R. Tech Bull Ministry of Agriculture, No. 11, 74pp

Hafez M, Fayad YH, El-Kifl AH (1979) Impact of the egg parasite Platytelenomus hylas Nixon on the population of the sugar-cane borer, Sesamia cretica Led. in Egypt. Bull Ent Soc Egypt Econ Ser 11(49):49-55

Hafez M, Tawfik MFS, Awadallah KT, Sarhan AA (1978-1979) Natural enemies of the cotton white fly, Bemisia tabaci (Genn.) in the world and in Egypt. Bull Soc Ent Egypte 62:9-13

Hafez M, Tawfik MFS, Ibrahim AA (1976) Survey and economic importance of parasites of the cotton leaf worm, Spodoptera littoralis (Boisd.) in Egypt. Bull Soc Ent Egypte 60:179-189

Hamed AR, Saad B (1989) Adaptation of Rodolia cardinalis Mulsant (Coleoptera: Coccinellidae) to Icerya aegytiaca and Icerya seychellarum Westw. Proc. 1st Int. confer. Econ. Ent, Cairo, Egypt, Vol. II, pp 33-38

Hassanein FA, El-Heneidy AH, Abbas MST, Hamed AR (1985) Survey of the parasitoids of main lepidopterous pests in vegetable fields in Egypt. Bull Soc Ent Egypte 65:259-265

Hassanein FA, Shoukry A, Sarhan AA, Ewais MA (1993) Biological studies on Opius nitidulator (Nees) (Hymenoptera: Barconidae), a newly recorded parasitoid on Pegomia mixta (Villeneuva). Egypt J Biol Pest Control 3(2):184-187

Hegazi EM, Herz A, Hassan S, Agamy E, El-Shazly MHA, Abo-Abdela L, Khamis N, El-Kemny S (2005) Naturally occurring Trichogramma species in olive farms in Egypt. Insect Science :185-192

Hegazi EM, Moursi KS (1983) Studies on distribution and biology of the capsule fly Acanthiophilus belianthi Rossi on wild plants in Egyptian Western Desert. Z ang Ent 96:333-336

Hekal AM, Sakr HE (2001) Morphology and biology of the immature stages of Aphytis holoxanthus Debach, a new recorded parasitoid of the black scale insect, Chrysomphalus ficus Ashm in Egypt. Egypt J Biol Pest Control 11(2):63-70

Hend OM, EL-Heneidy AH, Abd-Elalim GA, Azza AA (2016) Non-chemical control of the pink and spiny boll worms in cotton fields at Assuit Governorate, Upper Egypt, II- utilization of the egg parasitoid, Trichogrammatoidea bactrae Nagaraja. Egypt J Biol Pest Cont 26(4):807-813

Hosny MM, Assem MAH, El-Sayed AN (1966) Agricultural pests, p 1124 pp., (in Arabic) Ibrahim AA, Fayad YH (1983) Survey and identification of different species of aphids infesting certain cultivated and non-cultivated plants and their 
parasites in Egypt. Egyptian-Hungarian conference on plant protection, Budapest, June 1st, 1983, pp 1-24

Ibrahim AMA (1990) Hymenopterous parasitoids and hyperparasitoids on the cereal aphids Schizaphis graminum (Rond.), Rhopalosiphum maidis (F.), Rhopalosiphum padi L. and Sitobion avenae (Fab.) (Homoptera: Aphididae) on barley in Egypt. J Appl Sci 5(6):403-419

Ibrahim AMA (1994) Aphids and their parasitoids on apple trees at Giza region, Egypt. J. Biol. Pest Control 4(1):35-43

Ibrahim AMA, Amal IA (1991a) Seasonal fluctuation of English grain aphid Sitobion avenue (fab.) (Homoptera: Aphididae) on wheat and its primary parasitoids and hyperparasitoids in Giza Governorate. Egypt Bull Fac Agric Cairo Univ 22(1):167-182

Ibrahim AMA, Amal IA (1991b) The relationship between cereal aphids and aphidophagous syrphids, coccinellids, and chrysopids on wheat and barley in Egypt. Bull. Fac. Agric., Cairo Univ 22(1):183-191

Ibrahim AMA, Amal IA (1993) Population dynamics of the mealy plum aphid Hyalopterus pruni (Geoff.) and its associated parasitoids on peach. Egypt J Biol Pest Control 3(2):207-212

Ismail II, Abu-Zeid NA, Abdellah FF (1988) Ecological and behavioral studies on olive tree borers and their parasites. Agric Res Rev 66(1):145-152

Ismail II, Swailem SH (1971) Seasonal occurrence of Aphis nerii in Giza Region. Bull Soc ent Egypte LV:231-238

Kamal M (1951) The biological control of the leafworm Prodenia litura F. in Egypt. Bull. Soc. Fouad Ir Entomol, XXXV, pp 221-268

Karam HH, Sanaa SA-EK (1992) First record of Pulvinaria elongata Newstead (Homoptera: Coccidae) in Egypt. Alex J Agric Res 37(1):587-594

Khalafallah SA (1988-89) Biological and morphological aspects of the parasitoid, Scleroderma ephippium (Saunder) (Hymenoptera: Bethylidae). Bull Soc Ent Egypte 68:307-320

Khamiss O, Gianotti J, Fèdière G, Lèry X, Nour-El-Din A (1999) Characterization of two Egyptian isolates of Spodoptera littoralis (Boisduval) (Lepidoptera: Noctuidae) granulovirus from natural field infestation in Egypt. Proceedings of the first Regional Symposium for Applied Biological Control in Mediterranean Countries, Cairo Egypt, October 25-29, 1998, pp 147-152

Kolaib MO (1991) The role of parasitoids and hyperparasitoids associated with cabbage aphid Brevicoryne brassicae (L.) at Shebin El-Kom. Egypt J Biol Pest Control 11(1):19-22

Kolaib MO, Hegazi EM, Abdel Fattah MI (1980) Parasitoids of the Egyptian cotton leaf worm in Menoufia Governorate. Egypt Z angewandt Ent 89:193-198

Lamya MZ, Abdalla A (2015) Seasonal abundance of the citrus leaf miner, Phyllocnistis citrella, Stainton (Lepidoptera: Gracillariidae) and its parasitoids in Alexandria, Egypt. Egypt. J. Biol. Pest Control, 25(3), 2015, 597-602. Proceeding of 4th International Conference, ESPCP2015, Cairo Egypt, 19-22 October 2015

Lutfallah AF, Kares EA (1988-89) Ecological and biological observations on Bracon brevicornis Wesmeal (Hymenoptera: Braconidae), a parasitoid of corn borers in Egypt. Bull Soc Ent Egypte 68:187-193

Maha, M.A. Ibrahim; M.F.S. Tawfik and El-Husseini M.M. (2013). Seasonal abundance of Montandoniella morguesi Puton (Hemiptera: Phleothripidae) on Ficus nitida Thunb. at Giza Egypt Egypt J Biol. Pest Control, 23(1):187-188

Mahmoud SF (1981) Ecological studies on the California red scale and the purple scale insects on citrus trees and effect of some insecticides on them and their parasites. M Sc Thesis Fac Agric Cairo Univ Egypt :415

Marwa AMF, Sayeda SA, El-Husseini MM (2012) Life-history of Habrobracon hebetor Say (Hymenoptera: Braconidae) parasitizing Cadra (Ephestia) cautella (Walker) on dried date fruits. Egypt J Biol Pest Control 22(1):73-78

Meabed HAA, Amany M, Rizk NNE, El-Husseini MM (2011) Biocontrol agents compared to chemical insecticides for controlling the potato tuber moth, Phthorimaea operculella (Zeller) in the newly reclaimed land. Egypt J Biol Pest Control 21(1):97-100

Mesbah AH, Shoeb MA, El-Heneidy AH (2003) Preliminary approach towards the use of the egg parasitoid, Trichogrammatoidae bactrae Nagaraja against cotton bollworms in Egyptian cotton fields. Egypt. J Agric Res 81(3) (2003)): 981-995

Metwally AG, Shenouda K (1976) Relationship of Heliothis population in cotton fields, effectiveness of biological and chemical control. Agric Res Rev Cairo 54:1-7

Metwally SM, El-Heneidy AH, Shenishen Z, Boraei HA, Mesbah AH (1999) Clitostethus arcuatus (Rossi) (Coleoptera: Coccenillidae), a predator species, of the citrus whitefly, Dialerodes citri (Ashm.) (Homoptera: Aleyrodidae) in Egypt. Egypt J Biol. Pest Control 9(2):60-70

Metwally SAG (1991) Population studies on Liriomyza trifolii (Burgess) (Diptera: Agromyzidae) and its parasitoids. Egypt J Biol Pest Control 1(1):23-30
Morsi GA (1999) Studies on the natural enemies of scale insects infesting some fruit trees Ph.D. Thesis. Fac. Agric., Zagazig Univ :235

Mousa SF, El-Heneidy AH, Hindawy AS, Dalia A, Gonzalez D, Trjaptsyn SV (2001) Pink hibiscus mealy bug, Maconellicoccus hirsutus (green) parasitoids in Egypt. 1- preliminary record. Egypt. J Biol Pest Cont 11(2), (2001)):195-196

Nada MS (1994) Olive psyllid, Euphyllura straminea Loginova on olive, pest new to Egypt (Homoptera: Psyllidae). Egypt J Agric Res, (72):129-131

Nasr NF, Abou-Elkheir Stefanos S, Suzanne S, Youssef AA, Shehata WA (2002) New records of some biological control agents of Palpita unionalis Hubn. (Lepidoptera: Pyralidae) and Prays oleae Bern. (Lepidoptera: Yponomeutidae) in olive groves in Egypt. Egypt J Biol Pest Control 12(2):129-130

Neveen S, Gadallah A, El-Heneidy H, Mahmoud SM, Kavallieratos NG (2017) Identification key, diversity and host associations of parasitoids (Hymenoptera: Braconidae: Aphidiinae) of aphids attacking cereal crops. Zootaxa 4312(1):143-154 (2017)

Priesner H, Hosny M (1940) Notes on parasites and predators of Coccidae and Aleyrodidae in Egypt. Bull Soc ent Egypte 24:58-70

Ragab MEM (1988) Insects attacking corn ears in the field and their natural enemies. Ph.D. Thesis. Fac Agric Mansoura Univ :158

Ragab MEM (1991) Insects inhabiting safflower and the role of predatory insects in Mansoura. Egypt J Biol P Cont 1(1):11-18

Rakha MA, El-Naggar ME (1993) Predaceous mite populations in relation to citrus pests in Egypt. Egypt J Biol Pest Control 3(1):21-28

Rashad, A.M. (1975). Studies on the morphology, biology and ecology of the white mealy bug, Ferrisia virigata (Cockerell) in Egypt (Pseudococcidae: Homoptera). M. Sc. Thesis, Faculty of Agriculture, Cairo University. 195pp

Sarhan, A.A.A. (1981). A study on the natural enemies of the Mediterranean fruit flies Ceratitis capitata (Wied.). Ph.D. Thesis, Fac. Agric., Cairo University, Egypt, $211 p$

Sewify GH (1997) Occurrence and pathogenicity of entomopathogenic fungi in Egypt. The Seventh National Conference of Pests and Diseases of Vegetables and Fruits in Egypt, Ismailia 25-26 November 1997. Pp. 380-395

Sherif, M.R, A.S. Hendawy and M.M. EL-Habashy (2005). Management of rice insect pests

Shoukry AA, Sarhan AA, Caltagirone LE, Draz KA, Ahmed SA (1997) Ecological studies on the natural enemies of the honeydew moth, Cryptoblabes gnidiella (Mill.) in Mango orchards at Ismailia Governorate. Seventh National Conf. of Pests and Diseases of Vegetables and fruits in Egypt, Ismailia 25-26 November, Suez Canal Univ., 490-506

Swailem SM, Awadallah KT, Shaheen AA (1976) Abundance of Lindingaspis rossi Mask, on ornamental host plants in Giza and Zagazig regions. Egypt Bull Soc ent Egypte 60:257-263

Tawfik MFS (1967) Microfauna of the leaf-rolls of Ficus nitida Thumb- Hort. Bull Soc Ent Egypte LI :483-487

Tawfik MFS (2002) Biological control of insect pests in Egypt. Published by Egyptian Society for Biological Control of Pests, p 45

Tawfik MFS, Awadallah KT, Swailem SM, El-Maghraby MMA (1976b) The biology of Cardiastethus nazarenus Reuter. Bull Soc Ent Egypte 60:239-249

Tawfik MFS, El-Dakroury MSI, Afifi Amal I, Ibrahim AM, Eid FMH (1996) Parasitic species secured from larvae and pupae of the citrus leaf miner, Phylocnistis citrella Stainton, in Egypt (Phyllocnistidae: Lepidoptera). Egypt J Biol Pest Control 6(1, 111) (Scientific note)

Tawfik MFS, El-Sherif SI (1969) The Biology of Pyroderces simplex Wlsm. an important pest on maize plants in U.A.R. Bull Soc ent Egypte LIII:211-216

Tawfik MFS, El-Sherif SI, El-Heneidy AH (1976a) Insect fauna of Egyptian clover fields in the Giza Region. Egypt Bull Soc ent Egypte 60:171-178

Tawfik MFS, Kira MT, Metwally SMI (1974) A survey of the insect fauna of corn fields in U.A.R. Bull Soc Ent Egypte LVIII :145-152

Tawfik MFS, Mostafa H, Raouf A (1970) Survey of the natural enemies of the black scales, Chrysomphalus ficus Ashm. in the world and in U.A.R. Tech Bull Ministry of Agriculture 2:19-31

Tawfik MFS, Yousef AA, El-Adl MA, Ghenim AA, Ragab ME (1995) Diaperasticus erythrocephalus (Olivier), a newly recorded for ficulid (Dermaptera) in Egypt. Egypt J Biol Pest Control 5(1):61-65

Temerak SA (1978-1979) A preliminary survey on the soil inhabiting predaceous arthropods associated with pupae of the large sugar-cane borer Sesamia cretica in sorghum fields. Bull. Soc. ent. Egypte 62:251-255

Youssif MA, El-Arnaouty SA, El-Maghraby MM, El-Zohairy MM, Hammad KA (2014b) First record of the predatory species Wesmaelius navasi (Andreu, 1911) (Neuroptera: Hemerobiidae) in Egypt. Egypt J Biol Pest Control 24(2), 2014):531-532 
Youssif MAl, El- Heneidy AH, El-Maghraby MMA, El-Zohairy MMM, Hammad KAA (2014a) (2014a). Chrysemosa jeanneli (Navás, 1914) (Neuroptera: Chrysopidae), a new lacewing species recorded in Egypt. Egypt J Biol Pest Control 24(2): $529-530$

Zaher MA (1986) Survey and ecological studies on phytophagous, predaceous and soil mites in Egypt. II-Predators and nonphytophagous mites. Final Report, PL 480 program USA, Project No. EG ARS 30, p 567

Zappala L, Biondi A, Alma A, Al-Jboory IL, Arno J, Bayram A, Chailleux A, ElArnaouty A, Gerling D, Guenaoui Y, Shaltiel-Harpaz L, Siscaro G, Stavrinides M, Tavella L (2013) Rosa Yerchner Azner, Alberto Urbaneja and Nicolas Desneux (2013). Natural enemies of the South American moth, Tuta absoluta in Europe, North Africa and Middle East and their potential use in pest control strategies. J Pest Sci 86:635-647

\section{Submit your manuscript to a SpringerOpen ${ }^{\circ}$ journal and benefit from:}

- Convenient online submission

- Rigorous peer review

- Open access: articles freely available online

High visibility within the field

- Retaining the copyright to your article

Submit your next manuscript at $\boldsymbol{\nabla}$ springeropen.com 